\title{
Aircraft study of the impact of lake-breeze circulations on trace gases and particles during BAQS-Met 2007
}

\author{
K. L. Hayden ${ }^{1}$, D. M. L. Sills ${ }^{3}$, J. R. Brook ${ }^{1}$, S.-M. Li ${ }^{1}$, P. A. Makar ${ }^{1}$, M. Z. Markovic ${ }^{2}$, P. Liu ${ }^{3}$, K. G. Anlauf ${ }^{1}$, \\ J. M. O'Brien ${ }^{1}$, Q. $\mathbf{L i}^{4}$, and R. McLaren ${ }^{5}$ \\ ${ }^{1}$ Air Quality Research Division, Environment Canada, Toronto, ON, Canada \\ ${ }^{2}$ Department of Chemistry, University of Toronto, Toronto, ON, Canada \\ ${ }^{3}$ Cloud Physics and Severe Weather Research Section, Environment Canada, Toronto, ON, Canada \\ ${ }^{4}$ Meteorological Service of Canada Operations-Ontario, Environment Canada, Toronto, ON, Canada \\ ${ }^{5}$ Centre for Atmospheric Chemistry, York University, North York, ON, Canada
}

Received: 12 March 2011 - Published in Atmos. Chem. Phys. Discuss.: 13 April 2011

Revised: 8 September 2011 - Accepted: 26 September 2011 - Published: 10 October 2011

\begin{abstract}
High time-resolved aircraft data, concurrent surface measurements and air quality model simulations were explored to diagnose the processes influencing aerosol chemistry under the influence of lake-breeze circulations in a polluted region of southwestern Ontario, Canada. The analysis was based upon horizontal aircraft transects conducted at multiple altitudes across an entire lake-breeze circulation. Air mass boundaries due to lake-breeze fronts were identified in the aircraft meteorological and chemical data, which were consistent with the frontal locations determined from surface analyses. Observations and modelling support the interpretation of a lake-breeze circulation where pollutants were lofted at a lake-breeze front, transported in the synoptic flow, caught in a downdraft over the lake, and then confined by onshore flow. The detailed analysis led to the development of conceptual models that summarize the complex 3-D circulation patterns and their interaction with the synoptic flow. The identified air mass boundaries, the interpretation of the lake-breeze circulation, and the air parcel circulation time in the lake-breeze circulation $(3.0$ to $5.0 \mathrm{~h}$ ) enabled formation rates of organic aerosol $(\mathrm{OA} / \Delta \mathrm{CO})$ and $\mathrm{SO}_{4}^{2-}$ to be determined. The formation rate for $\mathrm{OA}$ (relative to excess CO in ppmv) was found to be $11.6-19.4 \mu \mathrm{g} \mathrm{m}^{-3} \mathrm{ppmv}^{-1} \mathrm{~h}^{-1}$ and the $\mathrm{SO}_{4}^{2-}$ formation rate was $5.0-8.8 \% \mathrm{~h}^{-1}$. The formation rates are enhanced relative to regional background rates implying that lake-breeze circulations are an important dynamic in the formation of $\mathrm{SO}_{4}^{2-}$ and secondary organic
\end{abstract}

Correspondence to: K. L. Hayden (katherine.hayden@ec.gc.ca) aerosol. The presence of cumulus clouds associated with the lake-breeze fronts suggests that these enhancements could be due to cloud processes. Additionally, the effective confinement of pollutants along the shoreline may have limited pollutant dilution leading to elevated oxidant concentrations.

\section{Introduction}

The temporal and spatial structure of the boundary layer and lower troposphere near coastlines can be complex due to radiative property differences between land and water. This can be an important feature affecting the transport and transformation of air pollutants in such regions. Temperature gradients between cooler air over water and warmer air over land result in a pressure gradient that can initiate and sustain a lake (sea) breeze during the day and a land breeze at night. During the day, air over a lake moves inland in a shallow inflow layer (typically $<500 \mathrm{~m}$ ) and air aloft over land moves offshore in a return flow to replace air from over the lake. As the cooler lake air moves over the warmer land surface, a thermal internal boundary layer (TIBL) is created which grows in height with an increase in inland distance (Lyons and Olsson, 1973; Garratt, 1990). At the leading edge of the lake breeze, air is forced upwards at the convergence zone (lake-breeze front) that separates the cooler lake air from the warmer air inland. The passage of a lake-breeze front is often characterized by increased upward motion, enhanced moisture and wind shear, decreased temperatures and changes in wind direction and speed (Lyons, 1972). Due to the upward motion of air at the lake-breeze front, a line of cumulus clouds may

Published by Copernicus Publications on behalf of the European Geosciences Union. 
form along the frontal zone. At night, the temperature gradient is reversed and a land breeze is formed.

Numerous studies have identified the importance of lake (sea) breeze circulations to air quality in coastal urban areas (e.g. McElroy and Smith, 1986; Lu and Turco, 1994; McKendry et al., 1997; Cheng, 2002; Snyder and Strawbridge, 2004; Bouchlaghem et al., 2008; Lin et al., 2010). Specifically, a number of studies have been conducted in the Great Lakes area to examine lake breezes and their influence on air quality (e.g. Biggs and Graves, 1962; Lyons, 1972; Lyons and Cole, 1976; Reid et al., 1996; Sills 1998; Hastie et al., 1999). The region of southwestern Ontario often experiences poor air quality due to elevated $\mathrm{O}_{3}$ and particulate matter (PM) concentrations (OME, 2008). The impact of the lakes and their associated lake-breeze circulations has been a complicating factor in elucidating chemical processes on a fine spatial scale in this region. For example, aircraft measurements showed that aged, polluted air masses over Lake Ontario were advected over land by lake breezes with abrupt increases in $\mathrm{O}_{3}$ concentrations, as well as other pollutants such as $\mathrm{NO}_{\mathrm{x}}$ and PAN (Reid et al., 1996; Hastie et al., 1999). However, the interaction between lake breezes, chemical transport and processes behind the increases is not well understood.

In the summer of 2007, the Border Air Quality and Meteorology Study (BAQS-Met) was conducted in southwestern Ontario to study the effects of lake breezes on air quality. This multi-agency, collaborative study was a unique opportunity to relate an intensive set of meteorological data to a comprehensive suite of trace gases and particle measurements in an area of frequent lake breeze activity. This paper presents a detailed analysis of a complete lake-breeze circulation using high spatially and temporally resolved meteorological and chemical measurements. Interpretation of the measurements in combination with air quality model simulations provides new insights into the complexities of lake-breeze circulations related to air mass processing.

\section{Experimental design}

The study area was located in the southern Great Lakes region between Lakes Huron, Erie and St. Clair (see Fig. 1). A meso-network of 50 stations spaced approximately $15 \mathrm{~km}$ apart collected measurements of meteorology, $\mathrm{O}_{3}$ and $\mathrm{PM}$ concentrations. These measurements were made from 1 June to 31 August, 2007. The sites relevant to the present analyses include Cottam, Essex, Woodslee, Lighthouse Cove, Lake St. Clair (LSC) Buoy and Sombra (Fig. 1). From 20 June to 10 July 2007, intensive measurements of gaseous compounds, particle chemistry and physics and meteorology were made at three supersites (Bear Creek $\left(42.5359^{\circ} \mathrm{N}\right.$, $\left.-82.3892^{\circ} \mathrm{W}\right)$, Harrow $\left(42.0330^{\circ} \mathrm{N},-82.8933^{\circ} \mathrm{W}\right)$ and Ridgetown $\left(42.4533^{\circ} \mathrm{N},-81.8878^{\circ} \mathrm{W}\right)$ (Fig. 1), and from an aircraft and a ground-based mobile laboratory, CRUISER. All times are in local time (LT) i.e. Eastern Daylight Savings Time.

\subsection{Flights}

The National Research Council of Canada (NRC) Twin Otter aircraft was deployed during the study and flew 16 flights over southwestern Ontario between 23 June and 8 July 2007. Flights were made during daytime (with the exception of one night flight) and at altitudes $<3000 \mathrm{~m}$ a.g.l. Slight adjustments were made to the flight paths to avoid flying through thick cloud. The date, time, and flight duration for each flight are provided in Table 1. Also shown for each flight are the daily synoptic wind direction, an assessment of the air quality (AQ) and predominant source region, and the identified lake-breeze type (Sills et al., 2011). Flight planning was supported by meteorological and air quality forecasting in the field.

\subsection{Aircraft instrumentation}

The Twin Otter was outfitted with fast-response meteorological instrumentation including 3-D winds, temperature, pressure, relative humidity, dewpoint temperature and radiation (National Research Council of Canada, 2008). The gas and particle instrumentation aboard the Twin Otter is summarized in Table 2. In-flight zeros and span checks for trace gas instrumentation were performed on each flight. Detailed calibrations of these instruments using National Institute of Standards and Technology (NIST)-traceable standards were done before and during the study. Particles were measured using an aerosol mass spectrometer (Aerodyne C-AMS), a Condensation Nucleus particle Counter (CNC), a Passive Cavity Aerosol Spectrometer Probe (PCASP), and a Particle Soot Absorption Photometer (PSAP).

The C-AMS deployed during this study provides mass concentrations and size distributions of particle chemical components with diameters less than $1 \mu \mathrm{m}\left(\mathrm{PM}_{1}\right)$. Previous versions of the AMS have been described in detail (Jayne et al., 2000; Jimenez et al., 2003) with more recent advancements provided in DeCarlo et al. (2006). The C-AMS has a compact time of flight mass spectrometer and was operated alternating between the mass spectrometric (MS) and particle time of flight $(\mathrm{PToF})$ modes with $30 \mathrm{~s}$ in each mode. Typically, fragments of mass to charge ratio $(\mathrm{m} / \mathrm{z})<300$ in the MS mode are used to determine mass concentrations of sulphate, nitrate, ammonium and total organics (Allan et al., 2003; Jimenez et al., 2003). During the study, continuous power was supplied to the instrument so that the pumps could provide constant vacuum and maintain a low background signal. On many occasions, the C-AMS signals were affected by low-level electronic noise, likely from cell phone towers in the area. The noise was most prevalent at mass fragments of $\mathrm{m} / z>100 \mathrm{amu}$, masking signals that are normally 

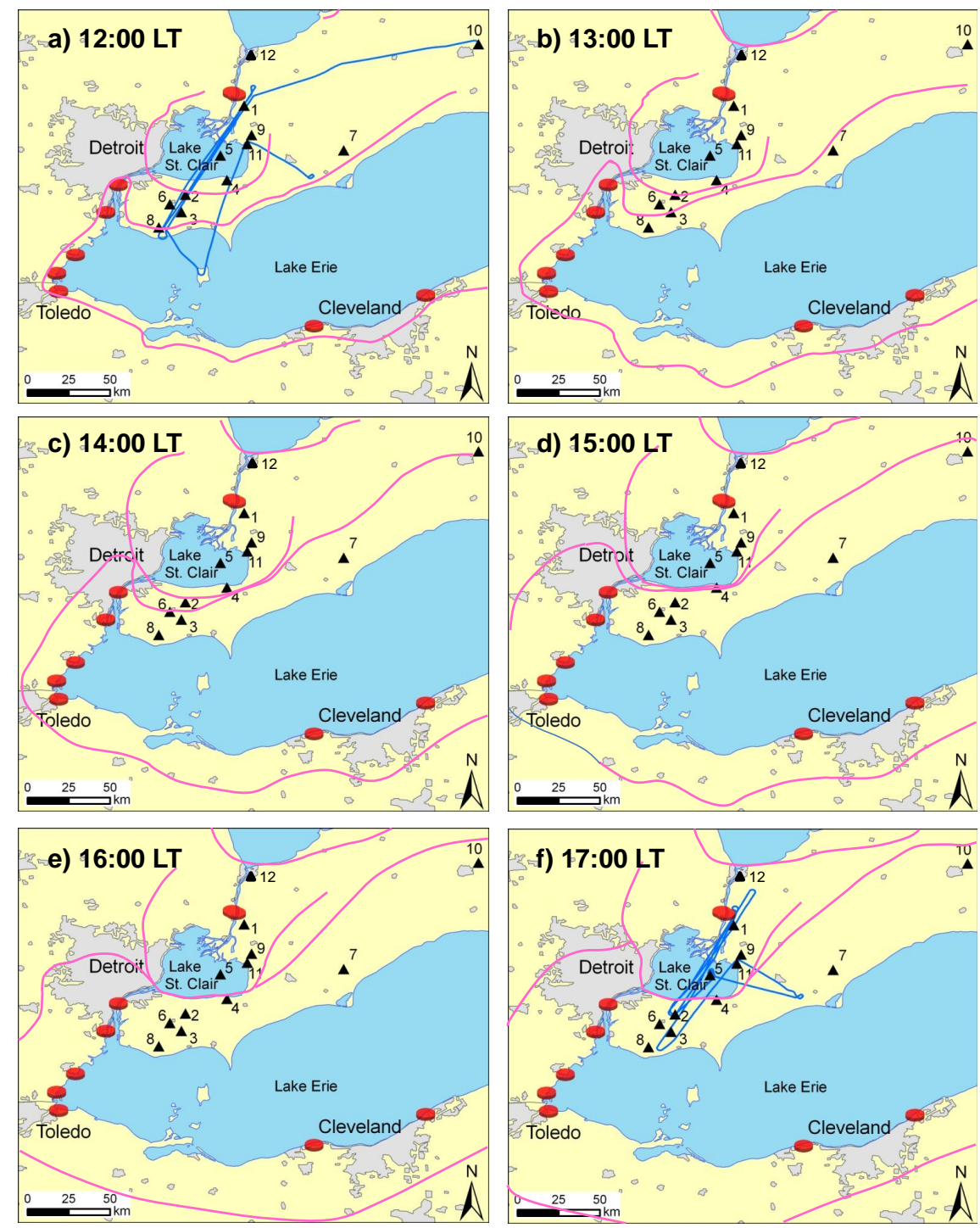

Fig. 1. Progression of lake-breeze fronts from 12:00-17:00 LT on 25 June. Position of lake-breeze fronts shown in magenta lines. Tracks for Flights 4 and 5 are shown as blue lines in (a) and (f) respectively. $\mathrm{SO}_{2}$ major point sources shown as red circles $\left(\mathrm{SO}_{2}>10000\right.$ tons/year). Surface sites in black triangles: (1) Sombra, (2) Woodslee, (3) Cottam, (4) Lighthouse Cove, (5) LSC buoy, (6) Essex, (7) Ridgetown, (8) Harrow, (9) Bear Creek, (10) London, (11) Mitchell's Bay, (12) Sarnia.

due to organics, if present. During periods of no cell phone interference, the organic mass determined with fragments $\mathrm{m} / \mathrm{z}<300$ amu was only $2.4 \pm 1.3 \%$ higher than the organic mass determined using a limited range of fragments, $\mathrm{m} / \mathrm{z}$ $<100$ amu. Therefore, since the organic mass including fragments $m / z>100 \mathrm{amu}$ was small, it was ignored in the organic mass determination. Five ionization efficiency calibrations were performed prior to and during the field campaign and showed very low variation $(<9 \%)$. Detection limits for 30 -s sampling duration were determined to be $0.270,0.024$, 0.014 and $0.073 \mu \mathrm{g} \mathrm{m}^{-3}$ for organics, $\mathrm{SO}_{4}^{-2}, \mathrm{NO}_{3}^{-}$and $\mathrm{NH}_{4}^{+}$, respectively. These detection limits are within the range of AMS detection limits reported (e.g. DeCarlo et al., 2006).

\subsection{Aircraft sampling inlets and particle collection efficiency}

Trace gases were sampled through a rear-facing $1 / 4$ " O.D. Teflon tube. Ozone, $\mathrm{SO}_{2}$ and $\mathrm{NO} / \mathrm{NO}_{2}$ were sampled through a pressure-controlled inlet that maintained a set-point pressure of $\sim 1 \mathrm{~atm}$ during flight to avoid pressure variations in these systems. The Aerolaser CO instrument did not sample through the pressure-controlled inlet.

Particles were sampled through a forward-facing near isokinetic stainless steel diffuser particle inlet. The inlet was mounted on the roof of the Twin Otter toward the front of the aircraft. Theoretical calculations taking into account the inlet dimensions, volume flow and velocity indicated $95 \%$ 
Table 1. Summary of Twin Otter flights showing the synoptic wind direction (based on back-trajectories analyses), an air quality descriptor (AQ), the lake breeze type (LD = Low Deformation; MD = Medium Deformation; HD=High Deformation; details in Sills et al., 2011), and $\mathrm{O}_{3}$ and $\mathrm{SO}_{4}^{2-}$ mean and maximum levels based on aircraft measurements.

\begin{tabular}{|c|c|c|c|c|c|c|c|c|c|c|c|}
\hline \multirow[t]{2}{*}{ Flt \# } & \multirow[t]{2}{*}{ Date } & \multirow{2}{*}{$\begin{array}{l}\text { Takeoff } \\
\text { Time } \\
\text { (LT) }\end{array}$} & \multirow{2}{*}{$\begin{array}{l}\text { Landing } \\
\text { Time } \\
\text { (LT) }\end{array}$} & \multirow{2}{*}{$\begin{array}{l}\text { Flight } \\
\text { Duration } \\
\text { (hh:mm) }\end{array}$} & \multirow{2}{*}{$\begin{array}{l}\text { Synoptic Wind } \\
\text { Direction }\end{array}$} & \multirow{2}{*}{$\begin{array}{l}\text { AQ/Source } \\
\text { Region }\end{array}$} & \multirow{2}{*}{$\begin{array}{l}\text { Lake Breeze } \\
\text { Type }\end{array}$} & \multicolumn{2}{|c|}{$\left[\mathrm{O}_{3}\right]$ (ppbv) } & \multicolumn{2}{|c|}{$\left[\mathrm{SO}_{4}^{2-}\right]\left(\mu \mathrm{g} \mathrm{m}^{-3}\right)$} \\
\hline & & & & & & & & Mean & $\operatorname{Max}$ & Mean & $\operatorname{Max}$ \\
\hline 1 & 23 June & $8: 52$ & $11: 15$ & $02: 23$ & Northwest & $\begin{array}{l}\text { Good/Local } \\
\text { sources }\end{array}$ & LD & 32.3 & 39.2 & 0.14 & 0.33 \\
\hline 2 & 23 June & $13: 30$ & $15: 57$ & $02: 27$ & Northwest & $\begin{array}{l}\text { Good/Local } \\
\text { sources }\end{array}$ & LD & 39.9 & 57.7 & 0.34 & 1.89 \\
\hline 3 & 23 June & $17: 43$ & $18: 16$ & $00: 33$ & Northwest & $\begin{array}{l}\text { Good/Local } \\
\text { sources }\end{array}$ & LD & 40.0 & 47.4 & 0.39 & 0.74 \\
\hline 4 & 25 June & $11: 01$ & $13: 24$ & $02: 23$ & Southwest & $\begin{array}{l}\text { Poor/Local } \\
\text { sources }\end{array}$ & LD & 64.9 & 84.1 & 4.70 & 15.13 \\
\hline 5 & 25 June & $15: 37$ & $17: 56$ & 02:19 & Southwest & $\begin{array}{l}\text { Poor/Local } \\
\text { sources }\end{array}$ & LD & 73.0 & 105.5 & 6.92 & 29.07 \\
\hline 6 & 25 June & $19: 13$ & $20: 07$ & $00: 54$ & Southwest & $\begin{array}{l}\text { Poor/Local } \\
\text { sources }\end{array}$ & LD & 71.8 & 84.1 & 7.79 & 10.72 \\
\hline 7 & 26 June & $08: 46$ & 11:06 & $02: 20$ & Southwest & $\begin{array}{l}\text { Poor/Long } \\
\text { range transport }\end{array}$ & MD & 67.5 & 87.2 & 6.00 & 25.51 \\
\hline 8 & 26 June & $13: 26$ & $15: 06$ & $01: 40$ & Southwest & $\begin{array}{l}\text { Poor/Long } \\
\text { range transport }\end{array}$ & MD & 71.3 & 93.3 & 4.35 & 14.89 \\
\hline 9 & 26 June & $16: 16$ & $18: 20$ & 02:04 & Southwest & $\begin{array}{l}\text { Poor/Long } \\
\text { range transport }\end{array}$ & MD & 70.3 & 93.2 & 4.81 & 18.59 \\
\hline 10 & 27 June & $08: 43$ & $09: 43$ & 01:00 & West & Detroit outflow & HD & 43.3 & 65.8 & 2.18 & 9.73 \\
\hline 11 & 27 June & $11: 17$ & $13: 41$ & $02: 24$ & West & Detroit outflow & HD & 62.9 & 85.2 & 2.98 & 8.20 \\
\hline 12 & 3 July & 19:00 & $21: 30$ & $02: 30$ & $\begin{array}{l}\text { South then } \\
\text { north }\end{array}$ & $\begin{array}{l}\text { Poor/Long } \\
\text { range transport }\end{array}$ & MD & 66.2 & 102.6 & 2.32 & 11.78 \\
\hline 13 & 7 July & $04: 35$ & $07: 17$ & $02: 42$ & Northwest & Detroit outflow & MD & 45.4 & 79.0 & 0.56 & 1.87 \\
\hline 14 & 7 July & $13: 44$ & $16: 20$ & $02: 36$ & Northwest & Detroit outflow & MD & 63.6 & 87.2 & 0.75 & 3.53 \\
\hline 15 & 8 July & $11: 36$ & $14: 14$ & $02: 38$ & West & Detroit outflow & $\mathrm{HD}$ & 66.5 & 87.2 & 2.47 & 7.41 \\
\hline 16 & 8 July & $18: 32$ & $21: 00$ & $02: 28$ & West & Detroit outflow & HD & 69.8 & 81.0 & 2.36 & 4.65 \\
\hline
\end{tabular}

Table 2. Summary of trace gas and particle instrumentation on the Twin Otter aircraft.

\begin{tabular}{|c|c|c|c|}
\hline Measurement & Principle of Operation & Instrument & Resolution (s) \\
\hline $\begin{array}{l}\text { Particle } \\
\text { composition }\end{array}$ & $\begin{array}{l}\text { aerosol mass spectrometry/time } \\
\text { of flight detection }\end{array}$ & Aerodyne C-AMS & 30 \\
\hline $\mathrm{O}_{3}$ & UV absorption & TECO 49 & 5 \\
\hline $\mathrm{CO}$ & VUV resonance fluorescence & Aerolaser & 1 \\
\hline $\mathrm{SO}_{2}$ & UV fluorescence & TECO $43 \mathrm{~S}$ & 10 \\
\hline $\mathrm{NO} / \mathrm{NO}_{2}$ & chemiluminescence, photolysis & TECO 42S & 20, alternating \\
\hline Particle number & light scattering & TSI 7610 CNC & 1 \\
\hline $\begin{array}{l}\text { Particle size } \\
\text { distribution } \\
(0.120-2 \mu \mathrm{m})\end{array}$ & light scattering & $\begin{array}{l}\text { PCASP (passive cavity aerosol } \\
\text { spectrometer probe) }\end{array}$ & 1 \\
\hline Black carbon & light absorption & $\begin{array}{l}\text { PSAP (particle soot absorption } \\
\text { photometer) }\end{array}$ & 1 \\
\hline
\end{tabular}


transmission efficiency for $\mathrm{PM}_{1}$ through the inlet. Air was drawn through a 0.5 inch O.D. stainless steel tube using controlled rapid air movement (RAM) from the aircraft at 70 LPM. The PSAP, CNC and C-AMS subsampled from this manifold. The residence time from the inlet tip to the AMS, CNC, and PSAP was $<1 \mathrm{~s}$. Sub-micron particles $(0.120-2 \mu \mathrm{m})$ were measured with the PCASP that was mounted in an under-wing pod (Liu et al., 1992).

The particle collection efficiency (CE) of the C-AMS for ambient measurements is typically determined through comparisons with other particle chemical measurements such as with the Particle Into Liquid Sampler-Ion Chromatography instrument (PILS-IC) and/or with mass estimated from instruments such as Scanning Mobility Particle Sizers (SMPS). The CE is a function of the particle transmission through the aerodynamic lens (Jayne et al., 2000; Liu et al., 2007), the efficiency of particles being focussed by the lens and directed onto the vaporizer (Quinn et al., 2006; Salcedo et al., 2007; Huffman et al., 2005; Jayne et al., 2000), and the extent to which particles bounce off the vaporizer (Matthew et al, 2008; Huffman et al., 2005). Many researchers have determined that a $\mathrm{CE} \sim 0.5$ for ambient particles (e.g. Dunlea et al., 2009; Kleinman et al., 2007a; DeCarlo et al., 2008; Drewnick et al., 2004; Allan et al., 2004). However, higher $\mathrm{CE}$ values between 0.5 and 1 were found for particles dominated by ammonium nitrate and for acidic particles (Quinn et al., 2006; Kleinman et al., 2007a). During BAQSMet, the aerosol neutralization ratio (ANR) defined as the molar ratio of ammonium to (sulphate + nitrate) indicated that the particles were neutralized most of the time with the exception of data taken in high concentration sulphate plumes, where the particles had not yet been neutralized by $\mathrm{NH}_{3}$. A comparison of mass concentrations from the C-AMS with those estimated from the PCASP indicated a CE of 0.5 for neutralized particles (ANR 1.0), but approached 1.0 for acidic particles $(\mathrm{ANR}<0.5)$. Therefore, the $\mathrm{C}$-AMS data in this study were adjusted using $\mathrm{CE}=0.5$ for neutralized particles transitioning linearly to a $\mathrm{CE}=1.0$ for acidic particles. A pressure controlled inlet (PCI) was used in front of the AMS to remove variations in particle sizing and transmission due to pressure changes in the aerodynamic lens of the AMS (Jayne et al., 2000; Hayden et al., 2008; Bahreini et al., 2008). In the PCI, a low pressure region, between a $200 \mu \mathrm{m}$ orifice upstream of the AMS inlet and a $130 \mu \mathrm{m}$ orifice in the AMS inlet (replacing the standard $100 \mu \mathrm{m}$ orifice) was maintained at a set point of 470 torr. This low pressure region was variably pumped so that the inlet pressure of the AMS was maintained at 1.3 torr. Under this configuration, no corrections to particle sizing were required for altitudes up to $3000 \mathrm{~m}$ a.g.l. during this study. Transmission efficiency experiments performed during and after the study indicated that particles were transmitted through the PCI with $100 \%$ efficiency.

\subsection{Model description}

The Unified Regional Air-quality Modelling System (AURAMS) model was used to support the BAQSMet field study. Details of the model are provided in Makar et al. (2010), but a brief description is presented here. The model has three main components: (1) a prognostic meteorological model GEM (Global Environmental Multiscale model: Côté et al., 1998); (2) an emissions processing system, (Sparse Matrix Operator Kernel Emissions: Houyoux et al., 2000; CEP, 2003); and (3) an off-line regional chemical transport model, the AURAMS Chemical Transport Model (CTM: cf. Cho et al., 2009; Makar et al., 2009; Gong et al., 2006). The AURAMS model was run with three nested grids at 42,15 and $2.5 \mathrm{~km}$ horizontal resolution, driven by $15 \mathrm{~km}$ (for the two courser resolutions) and $2.5 \mathrm{~km}$ GEM simulations. The driving meteorology simulations were created at the coarser $(15 \mathrm{~km})$ resolution from analyses updated every $6 \mathrm{~h}$, with $12 \mathrm{~h}$ simulations having $6 \mathrm{~h}$ of discarded spinup, the final $6 \mathrm{~h}$ being stitched together for a continuous set of meteorological inputs for AURAMS. The driving meteorology was stored in 15 min timesteps for the coarser AURAMS simulations, and 2 min timesteps for the $2.5 \mathrm{~km}$ resolution simulation. Makar et al. (2010) provide a detailed evaluation of the model performance showing comparisons to observations with the aircraft and identified the presence of very local-scale features. Model output at $2.5 \mathrm{~km}$ horizontal resolution is used in conjunction with the measurements to evaluate pollutant sources and transport into the study region, and provides a more comprehensive analysis of pollutant behaviour and processing during a lake-breeze event.

In addition to the AURAMS simulations, high resolution forward and backward trajectories were calculated using the Canadian Meteorological Centre (CMC) trajectory model (D'Amours et al., 2001). This model made use of the $2.5 \mathrm{~km}$ resolution, 2 min timestep GEM wind fields that were also used to drive AURAMS at its highest resolution. Back trajectory endpoints and forward trajectory starting points were chosen to help elucidate the flow patterns associated with the driving meteorology, as will be discussed in more detail.

\section{Results and discussion}

A brief summary of meteorological sampling conditions on aircraft flight days is provided in Table 1. A detailed analysis of the meteorology and lake breezes observed throughout the study has been described elsewhere (e.g. OME, 2008; Sills et al., 2011; Slowik et al., 2011). The synoptic wind flow was determined from the high resolution back trajectories computed for air parcels arriving into the study region at $500 \mathrm{~m}$ a.g.1. Large scale synoptic flow varied considerably, and lake breezes were identified on each day (Sills et al., 2011). The identification and classification of lake breezes in this study was based on meteorological data collected from 
several different sources including surface measurements, satellite observations of clouds, and radar data. The extent to which the lake-breeze circulations were deformed by the synoptic wind was used to classify lake breezes as Low Deformation (LD), Moderate Deformation (MD) or High Deformation (HD) (Sills et al., 2011). LD lake-breeze circulations are most similar to the classic textbook depiction, with the light synoptic wind regime allowing lake-breeze fronts to develop around the perimeter of the lake and air parcels to move along quasi-closed circuits. On the opposite end of the spectrum are HD lake-breeze circulations in strong synoptic wind regimes where lake-breeze fronts form only along segments of shoreline quasi-parallel to the synoptic wind and the influence of the lake-breeze circulation on the movement of air parcels is masked.

The highest $\mathrm{O}_{3}(\max =105 \mathrm{ppbv}$, mean $=73.0 \mathrm{ppbv})$ and $\mathrm{SO}_{4}^{2-}\left(\max =29.1 \mu \mathrm{g} \mathrm{m}^{-3}\right.$, mean $\left.=29.07 \mu \mathrm{g} \mathrm{m}^{-3}\right)$ levels were observed from the aircraft on 25 June under light to moderate southwesterly synoptic flow that contributed to a poor air quality episode between 24-27 June. On 25 June, lake breezes developed in association with each of the lakes in the region and aircraft flights (Flights 4 and 5) were designed to sample across an entire LSC lake-breeze circulation at multiple altitudes. Lake-breeze fronts are shown as magenta lines in Fig. 1. The light gradient flow on this day was conducive to the formation of lake-breeze fronts around LSC and along the edge of LE, and thus, classified as a LD (or a "classic") circulation. LD circulations occurred several times throughout the study period (Sills et al., 2011). In this paper, a complete lake-breeze circulation on 25 June is analyzed. Hourly surface mesoscale analyses (see Sills et al., 2011) are used as a guide to identify signatures of lake-breeze fronts in the aircraft meteorological data and compared with spatial and vertical changes in pollutant concentrations. Cross-sectional plots constructed from the aircraft data are analyzed in conjunction with model simulations to interpret pollutant transport and processing within the lake-breeze circulations. Conceptual models of the lake-breeze circulation are proposed followed by estimates of the lake breeze impacts on air mass processing of PM.

\subsection{Air mass history}

As shown in Fig. 1, the study region is impacted by local, anthropogenic emissions from urban centres including Sarnia to the north, Detroit/Windsor in the west/northwest, Toledo to the southwest and Cleveland on the south shore of Lake Erie (LE). Emissions of $\mathrm{SO}_{2}$ and $\mathrm{NO}_{\mathrm{x}}$ from power generating plants and oil/chemical refining plants in the region include the St. Clair (USA) and Lambton (Canada) stations (north of Lake St. Clair [LSC]), Monroe (western shore of LE), and Avon Lake and Cleveland Electric (south shore of LE). Major $\mathrm{SO}_{2}$ point sources $\left(\mathrm{SO}_{2}\right.$ emissions $>10000$ tons/year, United States Environmental Protection Agency (EPA, http://epa. gov/airmarkets); Canadian National Pollutant Release Inven- tory (NPRI, www.ec.gc.ca/inrp-npri/default.asp?lan=en)) are shown as red circles in Fig. 1. The region is further affected by local mobile and agricultural precursor emissions, ship emissions along the St. Lawrence Seaway from LE and along the Detroit River through to Detroit, and by longer-range transport of pollutants from midwestern US states.

On 25 June 2007, a weak pressure ridge extended from the New England states in the United States across the Great Lakes. The synoptic flow was light from the southwest. In Fig. 2, high resolution back trajectories (D'Amours et al., 2001) are shown arriving into the study region during the Flight 4 time period (11:01-13:24LT). The arrival points correspond to aircraft locations, times and altitudes selected along the Flight 4 track. Trajectories are coloured as a function of altitude. Figure 2 indicates that the predominant flow on 25 June was from the south to west-southwest with air masses having travelled over urban areas and power plants at the west end of LE. Figure 2 also shows that the back trajectories are sensitive to perturbations in air mass flow due to lake breezes. For example, over the Harrow site, the upwind flow was westerly, with transport of emissions from the west end of Lake Erie, but after the onset of the lake breezes (11:00 LT), the back trajectories switched to southerly closer to the site. This is consistent with surface measurements at Harrow that showed a change in wind direction from westerly to southerly at this time. The back trajectory at the south end of LSC also shows a change in direction from westerly to northeasterly in response to the LSC onshore lake breeze.

\subsection{Lake-breeze identification}

Mesoscale analyses for each hour (Sills et al., 2011) and the inland progression of the lake breezes from 12:00 to 17:00 LT pm on 25 June 2007 is presented in Fig. 1. The positions of the lake-breeze fronts are shown as magenta lines. Lake breezes on this day were first detected at 11:00 LT and persisted until 21:00 LT. At 12:00 LT (Fig. 1a), lake-breeze fronts were detected along the south and north shores of LE, as well as almost all the way around LSC. The north shore LE front progressed northward toward LSC until the LE and LSC fronts merged along the south shore of LSC at 15:00 LT (Fig. 1d). The merged fronts then remained quasi-stationary until after 17:00 LT.

On 25 June 2007, two of the three aircraft flights sampled across the LSC lake-breeze circulation. Aircraft tracks for Flights 4 and 5 are shown in Fig. 1a and f respectively, for the corresponding time interval in which they occurred. Flight 4 included horizontal transects between the north shore of LE (near the Harrow supersite) and near Lambton (north of the Sombra site) at $1560 \mathrm{~m}$ a.g.l. (free troposphere), $800 \mathrm{~m}$ a.g.l. and $300 \mathrm{~m}$ a.g.l. Flight 5 included a similar flight pattern with multiple transects at altitudes of $2600 \mathrm{~m}$ a.g.1., $1560 \mathrm{~m}$ a.g.l., $800 \mathrm{~m}$ a.g.l., $460 \mathrm{~m}$ a.g.l. and $300 \mathrm{~m}$ a.g.l. At the beginning of Flight 5, the aircraft performed a vertical spiral over the LSC buoy extending from $200-2600 \mathrm{~m}$ a.g.l. Using the analyzed 


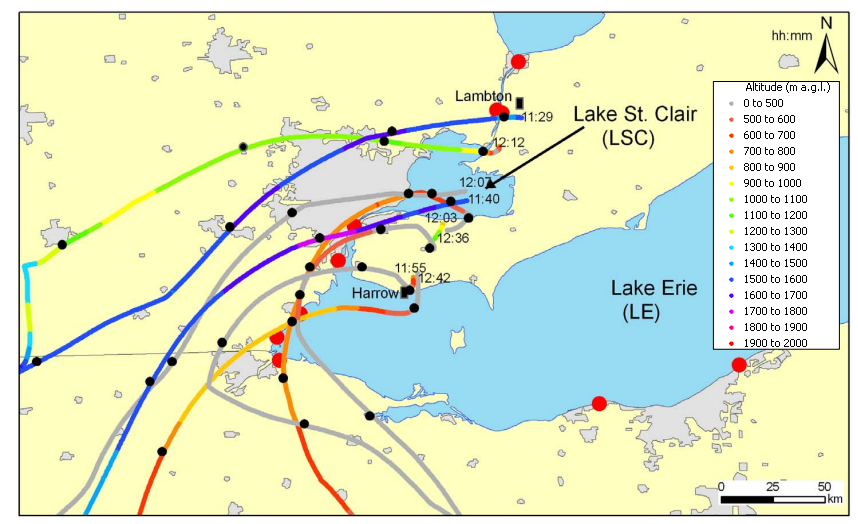

Fig. 2. High resolution back trajectories for 25 June arriving at selected locations and times along the Flight 4 aircraft track. Arrival times indicated as hh:mm. Trajectories are coloured by altitude (m a.g.1.). Black circles along trajectories every $4 \mathrm{~h} . \mathrm{SO}_{2}$ point sources shown as red circles $\left(\mathrm{SO}_{2}>10000\right.$ tons/year).

surface lake-breeze front locations as a guide, the aircraft meteorological and chemical data were examined to identify signatures due to lake breezes. On 23 June, low deformation lake breezes also occurred with even stronger lakebreeze convergence zones (Sills et al., 2011). Although, pollutant concentrations were low during this period of northwesterly synoptic flow (Table 2), aircraft data on this day were similarly analyzed for lake-breeze boundaries. It was found that on 23 June sharp changes in the dewpoint temperature and sustained upward gust velocities were good indicators of lake-breeze front crossings. This provided confidence that using these parameters to identify lake-breeze fronts on 25 June was applicable. This approach was also consistent with an independent detailed analysis of all flight data.

\subsection{Aircraft observations of trace gases, particles and meteorology}

The wind direction, dewpoint temperature, vertical gust velocity, $\mathrm{CO}, \mathrm{SO}_{2}$, particulate $\mathrm{SO}_{4}^{2-}$, and particulate organics (OA) are shown for Flights 4 and 5 in Figs. 3 and 4, respectively. The bottom axis is the distance between Lake Erie (LE) and Lambton (just past Sombra) (see Fig. 2 for locations), the blue horizontal bar represents LSC. Note that in order to compare one transect to the next, the data are plotted so that geographically LE is always on the left and Lambton is always on the right of the x-axis; this means then that the time (hh:mm) will either go from left to right or right to left depending on the direction of the aircraft transect. The grey arrow indicates the direction of flight. The blue and green arrows indicate the position of the lake-breeze fronts as identified from the aircraft data. The light blue boxes are selected time slices that are discussed in Sect. 3.7. Although the fronts above the surface were likely not in the same horizontal location as at the surface because of sloped frontal zones, the difference was likely small, i.e. $<1 \mathrm{~km}$. Thus, the mesoscale surface analyses were used to guide the front locations in the aircraft data. An additional complication considered in the analysis was the movement of the fronts over time i.e. between the 800 and $300 \mathrm{~m}$ a.g.l. aircraft passes in Flight 4, the LE front migrated northward approximately $10 \mathrm{~km}$. In Flight 4 , the $1560 \mathrm{~m}$ a.g.1. track was in the free troposphere above an estimated $1200 \mathrm{~m}$ a.g.l. synoptic inversion height (Fig. 3a1, a2). CO mixing ratios were $<140 \mathrm{ppbv}$ and $\mathrm{SO}_{2}$ was below detectable levels. Particle mass concentrations of $\mathrm{OA}$ and $\mathrm{SO}_{4}^{2-}$ ranged between $0.5-3 \mu \mathrm{g} \mathrm{m}^{-3}$. These observations are indicative of homogeneous regional background air. In the $800 \mathrm{~m}$ a.g.l. transect, travelling from LE to Lambton (Fig. 3b1), the LE lake-breeze front can be clearly identified by a $2{ }^{\circ} \mathrm{C}$ increase in the dewpoint from $18^{\circ} \mathrm{C}$ to $20^{\circ} \mathrm{C}$ (blue arrow at 11:56 LT), which coincides with the position of the lake-breeze front based on analyses of surface meteorological data. The increase in the dewpoint is due to updrafts at the front bringing up moister air from the surface. There was also a sudden increase in the aircraft vertical gusts (Fig. 3b1) and a visible line of clouds. At this altitude the aircraft was below the synoptic inversion, but above a shallower LE lake-breeze inflow layer (on the lake side of the front), and thus, the relatively low chemical levels (Fig. 3b2) reflect "residual" air or remnants of the previous day's convective boundary layer (Sills et al., 2011). The aircraft then crossed the LE front and measurements showed an increase in primary and secondary pollutants consistent with a polluted convective boundary layer. Elevated pollutant concentrations were observed over land from the LE lake-breeze front to the south shore of LSC. Guided by the location of the surface lake-breeze front, finding evidence of the presence of the south shore LSC lake-breeze front beneath the $800 \mathrm{~m}$ a.g.l. flight level was more difficult based on meteorology alone. Since CO is a relatively long-lived species in the troposphere, these measurements were examined for perturbations related to lake-breeze boundaries. A brief, sharp change in $\mathrm{CO}$ of $24 \mathrm{ppbv}$ (green solid arrow at 12:01 LT), was observed (Fig. 3b2) suggesting the influence of the lakebreeze front. This was coincident with an increase in the vertical gusts (Fig. 3b1). On the LSC side of the LSC front, pollutants remained elevated followed by a sharp decrease over the south shore of LSC. A LSC front north of LSC was not detectable in the aircraft data and there were no discernible features suggesting the presence of a surface-based front.

At Lambton, the aircraft turned around and travelled southward toward Harrow at $300 \mathrm{~m}$ a.g.l. As the aircraft passed over the south shore of LSC at 12:35 LT, the wind direction changed from southerly to northeasterly (Fig. 3c1). A northerly wind direction at this time was also measured at the LSC buoy $\left(42.425^{\circ} \mathrm{N},-82.558^{\circ} \mathrm{W}\right)$, Woodslee $\left(42.212^{\circ} \mathrm{N},-82.748^{\circ} \mathrm{W}\right)$ and Lighthouse Cove $\left(42.292^{\circ} \mathrm{N}\right.$, $-82.522^{\circ} \mathrm{W}$ ) mesonet stations (see Fig. 1 for site locations). This is due to the onshore LSC lake breeze and demonstrates that the aircraft was successful in penetrating and sampling 

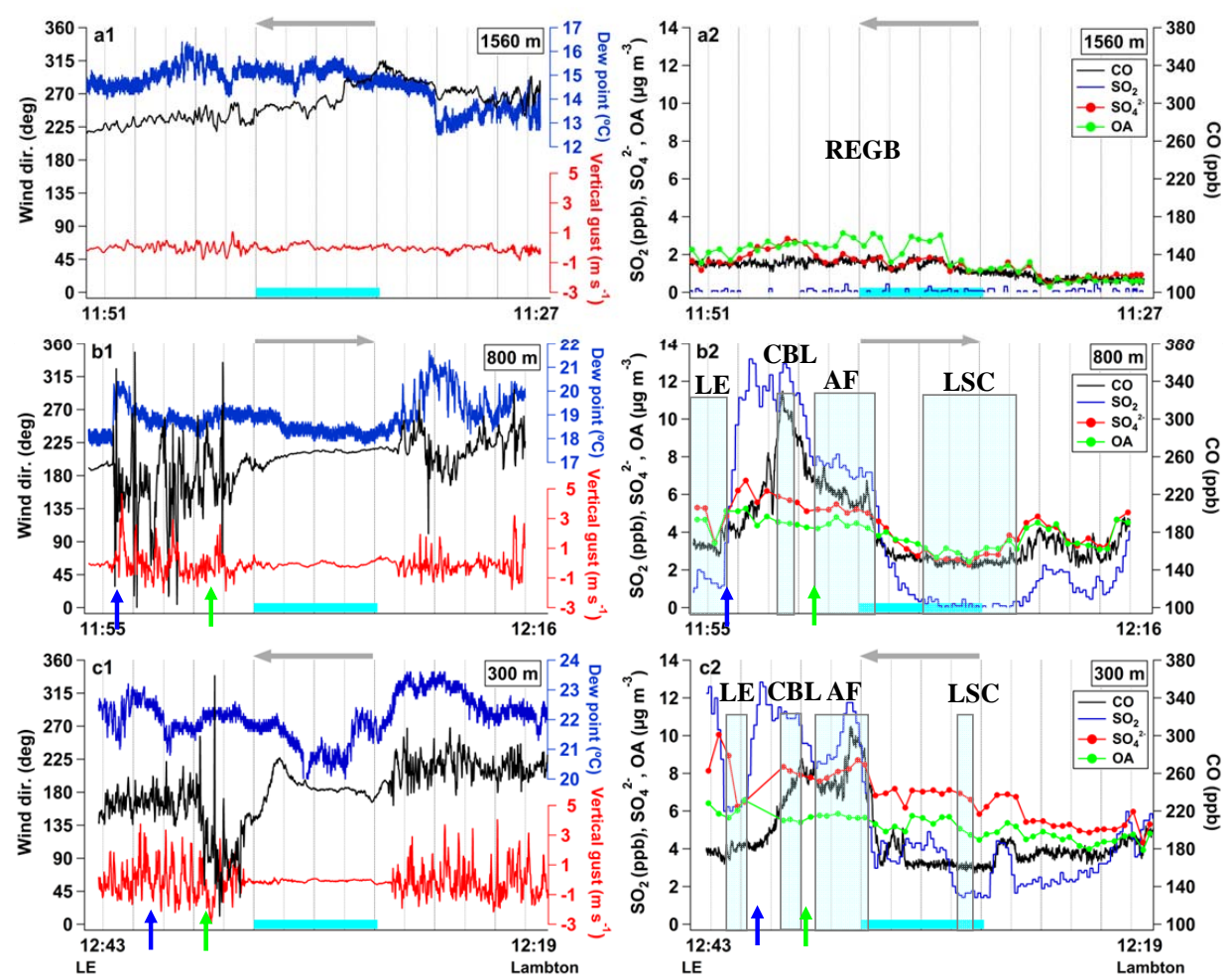

Fig. 3. Flight 4 wind direction, dewpoint, vertical gust velocity, $\mathrm{SO}_{2}, \mathrm{SO}_{4}^{2-}$, $\mathrm{OA}$, and $\mathrm{CO}$ measured from the aircraft along tracks at a) $1560 \mathrm{~m}$ a.g.l., b) $800 \mathrm{~m}$ a.g.l., and c) $300 \mathrm{~m}$ a.g.l. over LSC. Blue bar along horizontal axis = LSC; coloured arrows indicate lake breeze fronts (blue $=$ LE, green $=$ LSC). Data are plotted so that LE is on the left and Lambton is on the right of the x-axis and the direction of the aircraft transect is depicted as a grey arrow. Light blue boxes are selected time slices discussed in Sect. 3.7.

in the shallow lake-breeze inflow layer at $300 \mathrm{~m}$ a.g.l. Highest pollutant concentrations were between LE and just over the south shore of LSC which were generally consistent with levels at $800 \mathrm{~m}$ a.g.l. suggesting the development of a wellmixed convective boundary layer (CBL) (Fig. 3c2). Chan et al. (2011) also reported high surface concentrations of CO, $\mathrm{SO}_{2}$ and $\mathrm{SO}_{4}^{2-}$ near this time at the LSC shoreline to the northeast of the flight path. Concentrations were also observed to decrease sharply over the south end of LSC. Sharp changes in the dewpoint of $\sim 1^{\circ} \mathrm{C}$ signified the presence of the LE (12:39 LT) and LSC (12:37 LT) lake-breeze fronts, as supported by the surface mesoanalyses. The LSC front was also identified in the aircraft data by the onshore wind direction. Between Harrow and the LE lake-breeze front, plumes of $\mathrm{SO}_{2}$ and $\mathrm{SO}_{4}^{2-}$ were observed having been advected from over LE.

During the time between Flight 4 and Flight 5, $\sim 4$ h, the LE lake-breeze front pushed north $\sim 35 \mathrm{~km}$ and merged with the LSC front along the south shore of LSC by 15:00 (Fig. 1d). As a result, the CBL air between LE and LSC was replaced with lake air leaving the study region being largely influenced by lake-breeze circulations and lakemodified air masses. The first two transects in Flight 5 at $2600 \mathrm{~m}$ a.g.l. and $1560 \mathrm{~m}$ a.g.l. were in free tropospheric air. Figure $4 \mathrm{a} 1, \mathrm{a} 2$ shows the measurements from the transect at $1560 \mathrm{~m}$ a.g.l. indicating that the predominant flow was still from the southwest. As in Flight 4, low pollutant concentrations at the higher altitudes are believed to reflect regional background air. The measurements in the remaining transects (Fig. 4b-d) reflect residual air influenced or modified by lake-breeze return flow. Multiple, positive peaks in the updraft velocity at the three altitudes within the residual layer (16:36 LT (800 m a.g.l.), 16:43 LT (460 m a.g.1.), 17:20 LT (300 m a.g.l.)) are interpreted as updrafts along the merged LE/LSC lake-breeze front. Pollutant concentrations in this later afternoon flight were generally less variable compared to Flight 4 in the region between LE and LSC, but elevated pollutant levels were observed north of LSC, possibly originating from the CBL between LE and LSC, or pollutants from over LSC earlier that were advected northward and then mixed upward. North of $\mathrm{LSC} \mathrm{SO}_{4}^{2-}$ was $>15 \mu \mathrm{g} \mathrm{m}^{-3}$ and $\mathrm{CO}$, in particular, was variable ranging between 180-390 ppbv indicating a non-homogenous air mass. As the aircraft went further north just past Sombra, the measurements were likely influenced by power plant emissions from the Lambton area that were advected northeast in the southwesterly flow. 

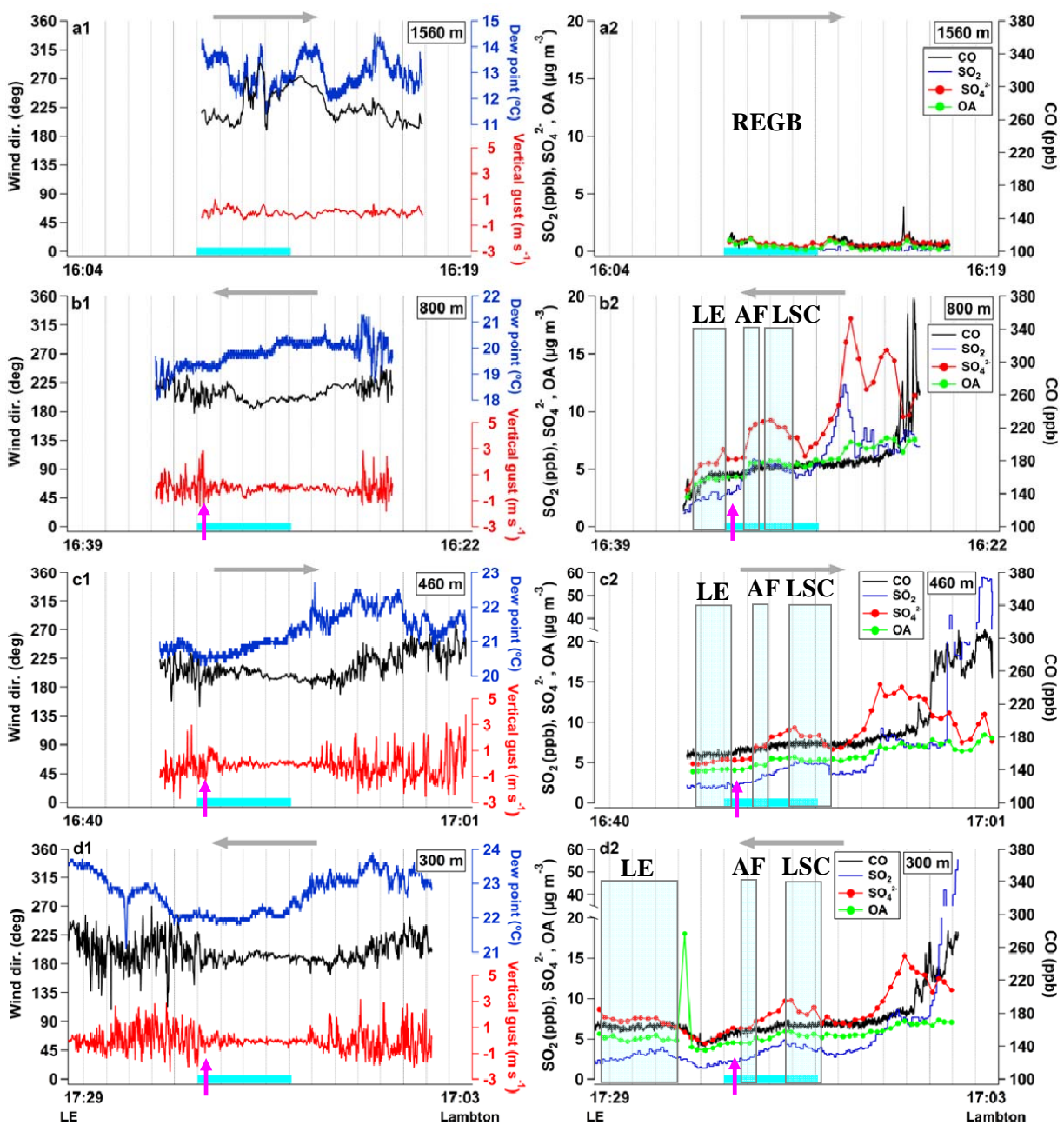

Fig. 4. Flight 5 wind direction, dewpoint, vertical gust velocity, $\mathrm{SO}_{2}, \mathrm{SO}_{4}^{2-}$, $\mathrm{OA}$, and $\mathrm{CO}$ measured from the aircraft along tracks at (a) $1560 \mathrm{~m}$ a.g.l., (b) $800 \mathrm{~m}$ a.g.l., (c) $460 \mathrm{~m}$ a.g.l., and (d) $300 \mathrm{~m}$ a.g.l. over LSC. Blue bar along horizontal axis = LSC; coloured arrow indicate lake breeze front (magenta $=$ LE/LSC merged front). Horizontal axis is fixed to geographical length of the longest transect; start/end times refer to data. Data are plotted as in Fig. 3. Light blue boxes are selected time slices discussed in Sect. 3.7.

\subsection{Distribution and evolution of trace gases and particles}

Data from the aircraft transects, averaged to $10 \mathrm{~s}$, and measurements from eight surface sites were interpolated using an ordinary linear kriging method (GS+ ver. 5.1.1, Gamma Design Software) to produce cross-sectional plots of $\mathrm{CO}, \mathrm{SO}_{2}$ and vertical winds (Figs. 5, 6). Overlaid on the plots are the interpolated plan-view horizontal wind directions (along with the corresponding orientation of the north arrow) and the size of the arrows represents the magnitude of the wind speed. The vertical wind component is not included in the wind direction, but is shown separately in the third panel of the figures to highlight the measured vertical motions. It was assumed that physical and chemical processes were sufficiently slow to build $2 \mathrm{D}$ cross sections from the aircraft tran- sects. Since there was some northward movement of the LE front during Flight 4 , the front locations are marked on each transect. $\mathrm{CO}$ and $\mathrm{SO}_{2}$ were chosen because they are both good tracers for different emission sources, both had fast instrument time responses (Table 2) and due to its 1 second time-response, $\mathrm{CO}$ appeared to be a good chemical tracer for lake-breeze motions. The surface sites chosen for this analysis were within $12.4 \mathrm{~km}$ horizontal distance of the Flight 4 and 5 mean flight path and included Harrow $(3.3 \mathrm{~km})$, Cottam $(1.3 \mathrm{~km})$, Essex $(5.7 \mathrm{~km})$, Woodslee $(0 \mathrm{~km})$, Lighthouse Cove $(12.4 \mathrm{~km})$, the LSC Buoy $(3.8 \mathrm{~km})$, Bear Creek $(11.4 \mathrm{~km})$ and Sombra $(0.8 \mathrm{~km})$ (Fig. 1a, f). The sites are indicated as black circles at the bottom of Figs. 5 and 6.

In Fig. 5, the LE lake-breeze front separates LE air and polluted CBL air. In Fig. 5c, a return flow associated with this front is not present, but an area of reduced wind speed 

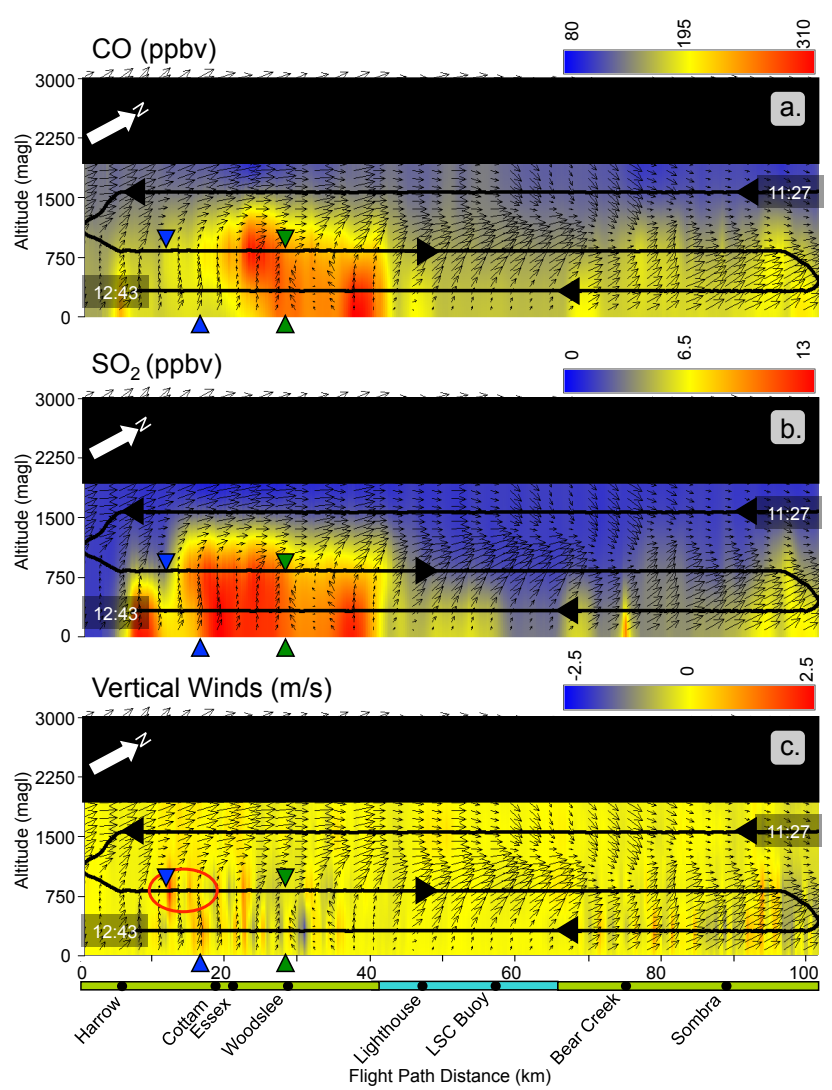

Fig. 5. Flight 4 cross-sections for (a) $\mathrm{CO}$, (b) $\mathrm{SO}_{2}$ and (c) vertical wind gusts along the axis of the transect. Horizontal wind direction overlaid (vertical wind component not included) and arrow size $=$ wind speed magnitude. Land $=$ green bar; lake $=$ blue bar. Arrows indicate lake breeze fronts (blue $=\mathrm{LE}$, green $=\mathrm{LSC}$ ). Artefacts due to lack of data have been blacked out.

(red circle) suggests that it may have been masked by the larger synoptic flow with a resulting net flow along the axis of the transect (southwesterly). Updrafts associated with convective motion were observed in the CBL, and a significant downdraft was measured on the LSC side of the LSC lake-breeze front. The synoptic inversion is estimated to be $\sim 1200$ ma.g.l. In Fig. 5, $\mathrm{CO}$ and $\mathrm{SO}_{2}$ were observed to be well mixed vertically within the CBL consistent with increased convection over the land surface. Transport of emissions from Detroit/Windsor and western LE in the southwesterly flow likely contributed to the elevated pollutant concentrations observed over land between LE and LSC. A horizontal gradient in $\mathrm{CO}$ mixing ratios was observed with highest levels further north compared to $\mathrm{SO}_{2}$ mixing ratios which were elevated in the entire region between LE and LSC. This is consistent with the back trajectories (Fig. 2) that show air masses that arrived near Harrow had crossed over $\mathrm{SO}_{2}$ emission sources at the west end of LE, whereas other trajectories arriving at points further north of Harrow also crossed over the Detroit/Windsor urban area. At the Harrow super-

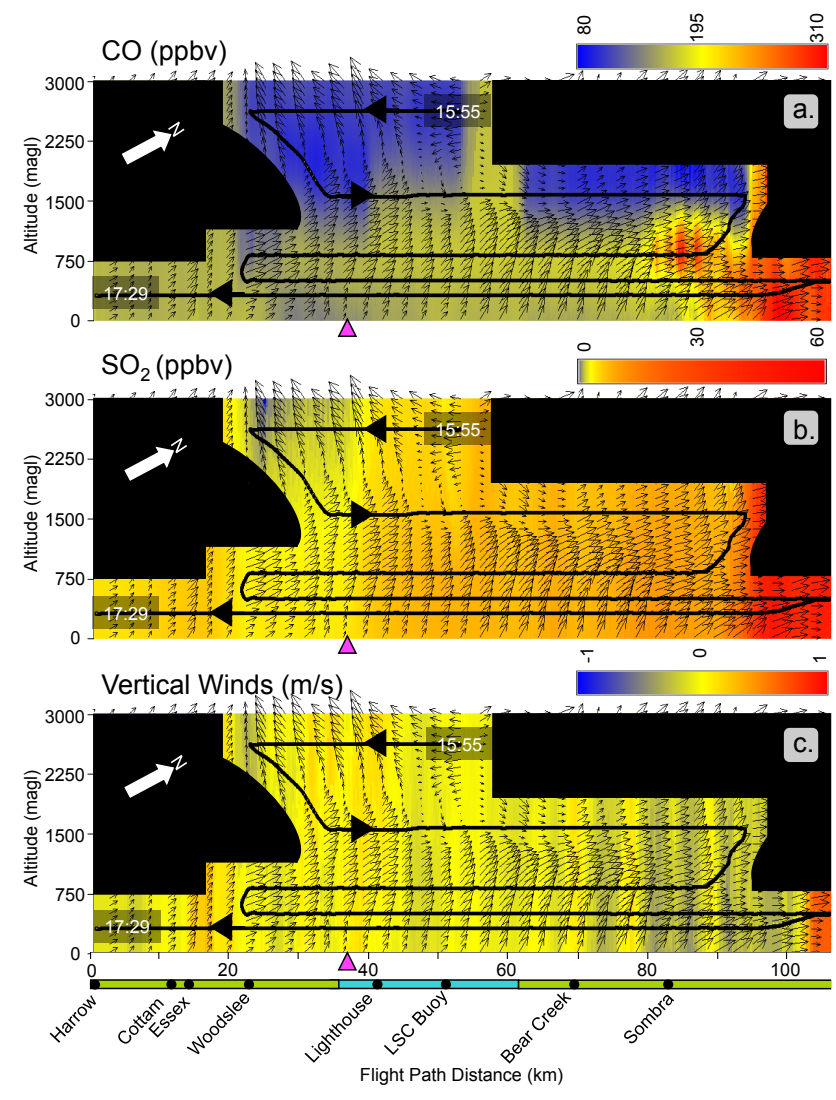

Fig. 6. Flight 5 cross-sections for (a) $\mathrm{CO}$, (b) $\mathrm{SO}_{2}$ and (c) vertical wind gusts along the axis of the transect. Horizontal wind direction overlaid (vertical wind component not included) and arrow size $=$ wind speed magnitude. Land=green bar; lake=blue bar. Magenta arrows indicate LE/LSC merged lake breeze front. Artefacts due to lack of data have been blacked out.

site, $\mathrm{SO}_{2}$ was observed to be "plume-like"; elevated $\mathrm{SO}_{2}$ was observed between 10:00-11:20 LT with mixing ratios reaching $>100 \mathrm{ppb}$. Although lake-breeze circulations were present around LE with onshore flow near Toledo, in order for plumes of $\mathrm{SO}_{2}$ to travel northward, they were either lofted over top of the lake-breeze inflow and/or were in transit prior to the formation of the lake breezes. Based on aircraft measurements, the spatial extent of the $\mathrm{SO}_{2}$ plumes is estimated to range between $7.0-13.5 \mathrm{~km}$ horizontally; this indicates that the plumes were remarkably intact suggesting minimal dispersion, and thus mostly transported over the lake. Lyons and Pease (1973) found that plumes from power plants travelled long distances over Lake Michigan with little dilution and attributed this to the absence of convective mixing over the lakes. It might be expected that if the plumes had travelled over top of the lake-breeze inflow, they would have undergone some mixing and dilution. The back trajectories indicate a 4-6h transit time from the west end of LE to arrive near Harrow (Fig. 2) and since this is prior to the onset of the lake breezes, the likely explanation for the $\mathrm{SO}_{2}$ was that 
the plumes were already in transit and not affected by local lake breeze mixing at the western end of LE. In addition, the observations from the later afternoon flight do not show an influence from $\mathrm{SO}_{2}$ emissions (except north of LSC from other sources, Figs. 4, 6) suggesting that the lake-breeze onshore flow near Toledo, which was still present at this time (Fig. 1), impedes transport to the study region even though the large scale flow continues to be southwesterly.

Elevated mixing ratios of $\mathrm{CO}$ and $\mathrm{SO}_{2}$ were also observed on the LSC side of the LSC lake-breeze front (Figs. 3, 5). The sharp decrease of pollutant levels at the LSC shore points toward important differences between lake and land surfaces and influences from the lake-breeze circulation. From Fig. 5, it is hypothesized that pollutants in the CBL were lofted upward at the LSC lake-breeze front, transported northward in the synoptic flow, transported in the downdraft on the north side the front, and then confined by the LSC onshore flow along the south shore of LSC. This is plausible since some of the CBL air closest to the LSC front would be expected to be advected in the upward vertical motion at the frontal convergence zone, and the downdraft that was measured behind the front (Fig. 5c) would draw air from above. This is hypothesized to result in the transport, at least partially, of air from the CBL to behind the LSC front within the lake-breeze circulation. The pollutants are then confined along the LSC shoreline by the onshore lake breeze. Another possible circulation pattern could be that pollutants already present behind the LSC lake-breeze front were lofted upward at the front, transported northward, caught in the downdraft and confined along the south shore of LSC. Pollutants from the CBL, also appear to have been transported northward and observed during the later Flight 5 time period discussed below.

Figure $3 \mathrm{~b} 2$, c2 shows that $\mathrm{CO}$ and $\mathrm{SO}_{2}$ behind the LSC front are confined to lower layers and not mixed through the same depth as the CBL. This could be because the development of a thermal internal boundary layer (TIBL) behind the lake-breeze front growing vertically with inland distance would not get as high as the fully developed CBL in the short distance between the lake shore and the front. This would result in pollutants within the TIBL being mixed over a shallower layer, and thus less diluted, compared with the CBL. The lake-breeze effect of confining pollutants is also evident at the surface. During the time of Flight 4, significant levels of $\mathrm{SO}_{2}(>50 \mathrm{ppb})$ and $\mathrm{SO}_{4}^{2-}\left(>35 \mu \mathrm{g} \mathrm{m}^{-3}\right)$ were observed by the CRUISER mobile laboratory from 12:40-13:10 LT at Mitchell's Bay, located on the shoreline at the eastern edge of LSC (see Fig. 1) (Chan et al., 2011). Also along the eastern shoreline, at Bear Creek, $\mathrm{SO}_{2}$ was 15-20 ppb from 11:0012:30 LT. There was no evidence of any significant pollutant build up north of LSC, which could be because there was less impact from sources along the back trajectory path (Fig. 2) and/or the weaker offshore lake-breeze circulation compared to the south and east sides of the lake. Mechanisms to transport pollutants within a lake-breeze circulation have been identified in previous studies (Lyons, 1972; Lyons and Cole, 1976; Sills et al., 1998) and are known to be effective in confining pollutants to coastal regions (Simpson, 1994; Lu and Turco, 1995). Dynamics at the lake-breeze front have been studied to understand effects on pollutants. Hastie et al. (1999) noted that the arrival of the lake breeze coincided with maximum trace gas concentrations with rapid decreases behind the front suggesting that vertical mixing generated by the front could result in entrainment of cleaner air from above the inflow layer. Kitada and Kitagawa (1990) showed that the vertical profile of pollutants was strongly impacted by the micro-scale features of the sea breeze such as the transport of pollutants in the downdraft behind the front and suggested that the most aged air mass would be found in the upper part of the circulation behind the front. Since lake and land breezes are quasi-closed circulations and pollutants emitted into them can be recirculated (Lyons, 1972), it might be expected that air in the downdraft of the LSC lake-breeze front would exhibit characteristics of a more aged air mass relative to the air in the $\mathrm{CBL}$. The impact of lake breezes on air mass processing is discussed further in Sect. 3.7.

In Fig. 6, a signature of the merged LE/LSC front is not apparent, but surface analyses show that the front was still present just offshore at 17:00 LT and by 19:00 LT the LSC lake breeze moved back onshore, with a shift to onshore winds and a rapid increase in dewpoint. The height of the synoptic inversion, determined from a vertical profile performed over the LSC buoy (15:47-15:55 LT), was $1300 \mathrm{~m}$ a.g.l. It is noted that strong east-southeast winds were measured above the merged front at the $2600 \mathrm{~m}$ a.g.l. level which is consistent with 08:00 LT and 20:00 LT DTX soundings showing winds with an easterly component between 2 and $3 \mathrm{~km}$. In Flight 5, pollutant concentrations, compared to Flight 4 , were more homogeneous across the flight transect. In Fig. 6, with the exception of the north end of the flight track near Lambton, $\mathrm{CO}$ and $\mathrm{SO}_{2}$ levels were lower and less variable compared to Flight 4 . The region is largely enveloped in lake-modified air and pollutants in the CBL observed in Flight 4 appear to have been displaced by the merging LE/LSC lake-breeze fronts. Thus, by 16:00 LT, only low primary pollutant concentrations remained between LE and LSC. The region having been fed by regional lake air from the south and influenced by lake-breeze circulations is expected to exhibit characteristics of a more aged air mass and is discussed further in Sect. 3.7. Pollutants from the CBL between LE and LSC in Flight 4 appear to have been lofted at the LSC front and carried northward by the southerly flow resulting in increased concentrations of pollutants northeast of LSC. Pollutants would be transported to the surface by land-based convection.

\subsection{Analysis of model-generated lake-breeze circulation}

A more comprehensive view of the lake-breeze circulations is possible through analysis of model data. In Fig. 7, modelpredicted $\mathrm{SO}_{2}$ mixing ratios overlaid with wind direction 


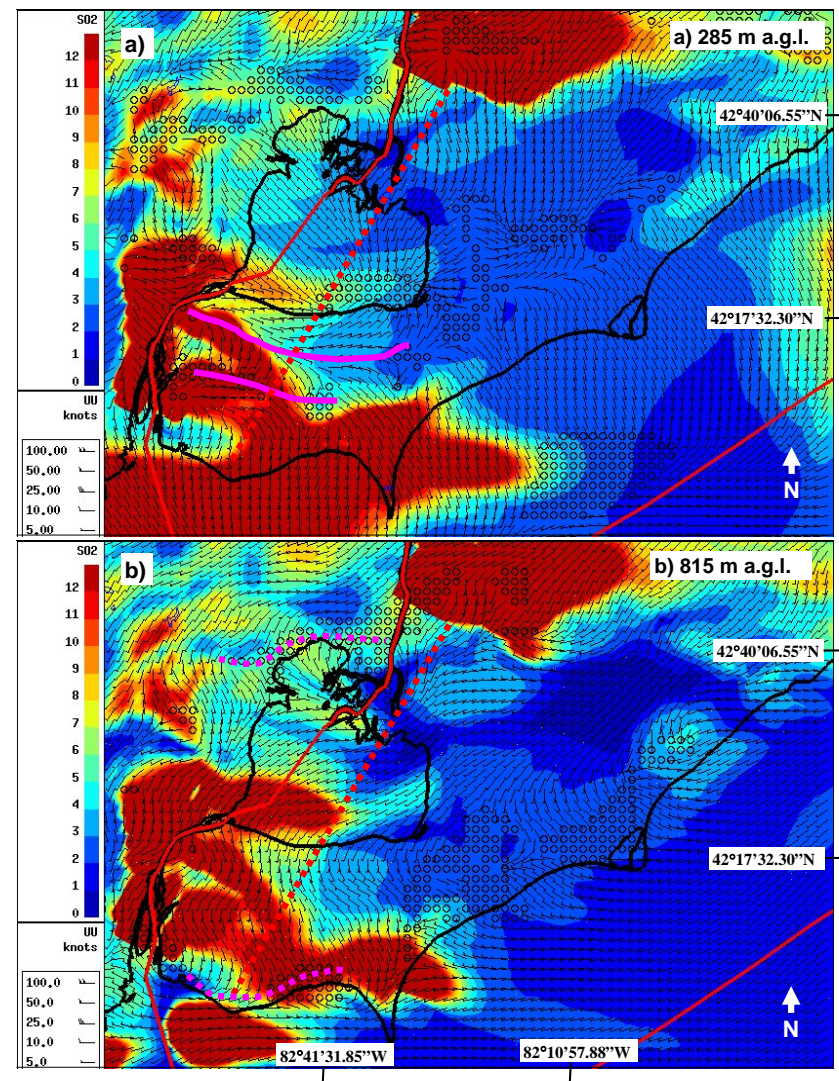

Fig. 7. Model-predicted $\mathrm{SO}_{2}$ mixing ratios overlaid with wind direction at (a) $285 \mathrm{~m}$ a.g.1. and (a) $815 \mathrm{~m}$ a.g.1 at 12:00 LT. Solid magenta line indicates surface convergence at the LE and LSC lake breeze fronts and dashed magenta line indicates divergence flow aloft. Dashed red line is the aircraft transect.

are shown at 12:00 LT for altitudes of (a) $285 \mathrm{~m}$ a.g.l. and (b) $815 \mathrm{~m}$ a.g.l. The model altitudes are the closest available to the 300 and $800 \mathrm{~m}$ a.g.l. aircraft transects, and the model simulation time corresponds to the middle of Flight 4. After 16:00 LT, the model predicts winds shifting to come from the southeast, while the observations indicate a continuation of southwesterly flow (Figs. 4 and 6). Figure 7a shows two zones of convergence (solid magenta lines) corresponding to the model's predicted locations of the LE and LSC fronts across the Flight 4 aircraft transect (red dashed line). Figure $7 \mathrm{~b}$ shows a region of divergence (dashed magenta lines) along the north shore of LE in response to the convergence at lower levels. The modelled wind direction along the aircraft transect is quite similar to the measured winds shown in Fig. $3 \mathrm{~b} 1$ and $\mathrm{c} 1$ for the corresponding altitudes. This provides confidence that the model is correctly simulating both the synoptic flow and lake-breeze circulation at this time. Figure 7 shows that high concentrations of $\mathrm{SO}_{2}$ are located over LE (and over the Lambton area to the northeast of LSC); these pollutants originated from sources on the west end of the lake and were advected into the study region by 12:00 LT, the Flight 4 time period.
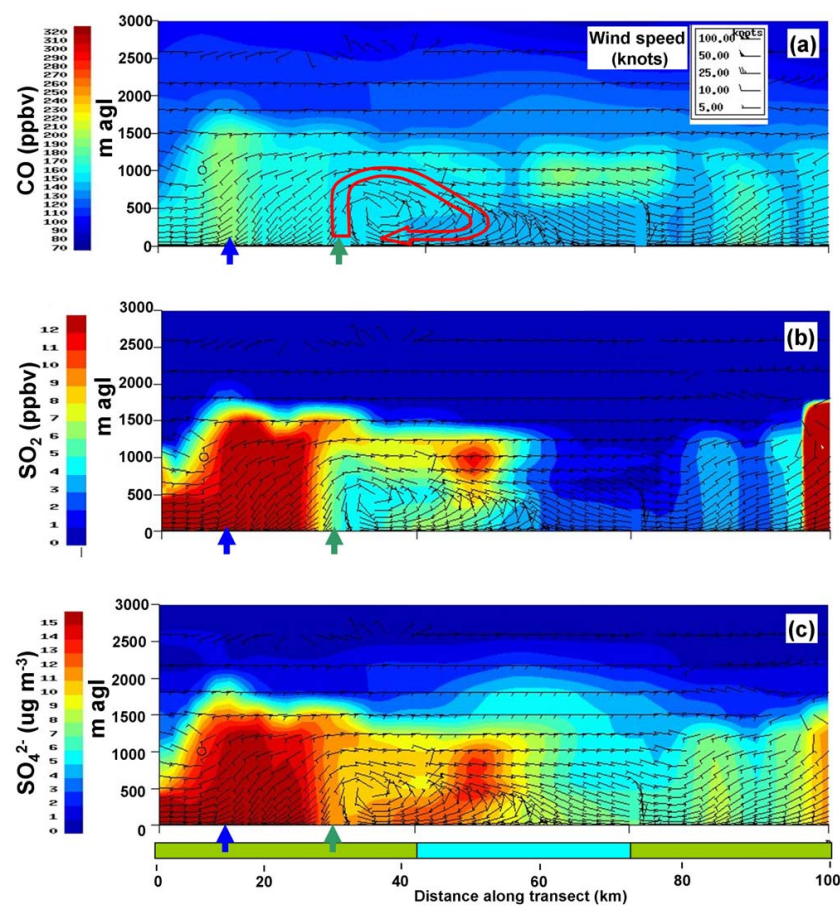

Fig. 8. Vertical cross section for model-predicted (a) $\mathrm{CO}$ and (b) $\mathrm{SO}_{2}$ and (c) $\mathrm{SO}_{4}^{2-}$ at 12:00 LT along the axis of the aircraft transect (dashed red line in Fig. 7). Wind direction overlaid is the 3-D wind field in the plane of the cross-section and, thus can be used to indicate horizontal and vertical motion in the plane of the crosssection. Red arrow in panel (a) represents the LSC lake-breeze motions. Land = green bar; lake = blue bar. Coloured arrows indicate lake breeze fronts $($ blue $=$ LE, green $=$ LSC).

In Fig. 8, vertical cross-sections of model-predicted (a) $\mathrm{CO}$, (b) $\mathrm{SO}_{2}$ and (c) $\mathrm{SO}_{4}^{2-}$ are shown along the aircraft flight track at 12:00 LT (red dashed line in Fig. 7) corresponding to the Flight 4 time period. The wind direction overlaid is the 3$\mathrm{D}$ wind field in the plane of the cross-section and, thus can be used to indicate horizontal and vertical motion in the plane of the cross-section. Consistent with the observations, the wind vectors show convergence zones marking the LE (blue arrow) and LSC lake-breeze (green arrow) fronts at lower altitudes ( $<\sim 600 \mathrm{~m}$ a.g.l.). The model results suggest a circulation where air just south of the LSC lake-breeze front (in the CBL) moves upwards and northward over LSC, gets caught in the downdraft behind the front, and moves ashore in the LSC lake breeze; the red arrow in Fig. 8a depicts this motion in the plane of the flight path. The model has a similar distribution in pollutants along the flight track as in Figs. 3 and 5. High pollutant levels are predicted to be south of $\mathrm{LSC}$ with $\mathrm{CO}$ and $\mathrm{SO}_{2}$ well-mixed up to $1500 \mathrm{~m}$ a.g.l., consistent with the observations. However, the model shows elevated $\mathrm{CO}$ mixing ratios in a narrow region at the LE lakebreeze front. Also, the model has high levels of $\mathrm{CO}, \mathrm{SO}_{2}$ and $\mathrm{SO}_{4}^{2-}$ at altitudes above $600 \mathrm{~m}$ a.g.l. over LSC, absent 


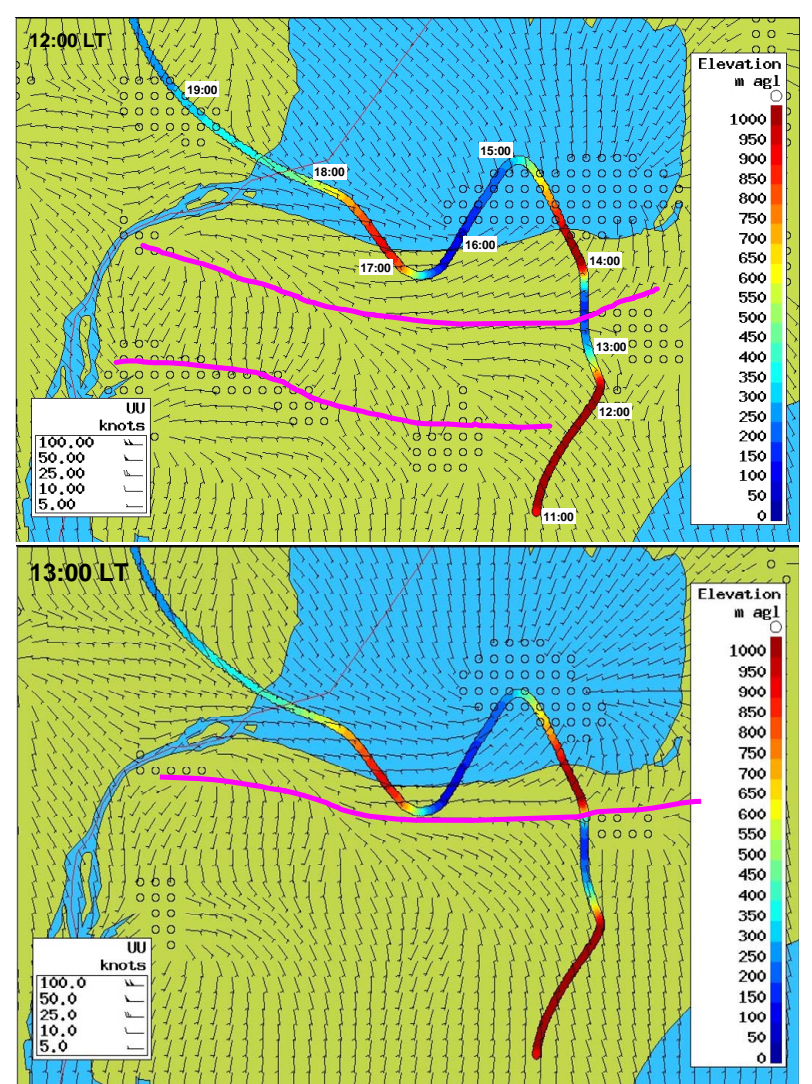

Fig. 9. Forward air parcel trajectory overlaid on the $285 \mathrm{~m}$ a.g.l. model wind fields at (a) 12:00 LT and (b) 13:00 LT.

in the observations. In the CBL between the LE and LSC fronts, CO mixing ratios of 160-170 ppbv are lower than the observations (180-340 ppbv). At the LSC front the model simulates a sharp decrease in all three species on the lake side of the LSC front, whereas the observations show higher values extending closer to the shore. In the circulation behind the LSC front, the model shows the downward transport of pollutants from aloft over the south end of LSC and the LSC lake-breeze appears to move the pollutants along the south shore of LSC consistent with the interpretation of the measurements.

In an effort to further investigate the behaviour of the LSC lake-breeze circulation and the possible connection between air in the CBL and air behind the LSC front, a number of forward trajectories derived from the same GEM meteorological data used in the air quality simulations, were computed. In Fig. 9, a forward air parcel trajectory is shown overlaid on the $285 \mathrm{~m}$ a.g.l. model wind fields at (a) 12:00 LT and (b) 13:00 LT. Although, the model predicts the LE and LSC fronts merging earlier than shown by the observations, the trajectory shows that as the LE and LSC fronts begin to merge, the air parcel drops in altitude, then increases to $\sim 1000 \mathrm{~m}$ a.g.1., and travels northward a little ways over LSC.
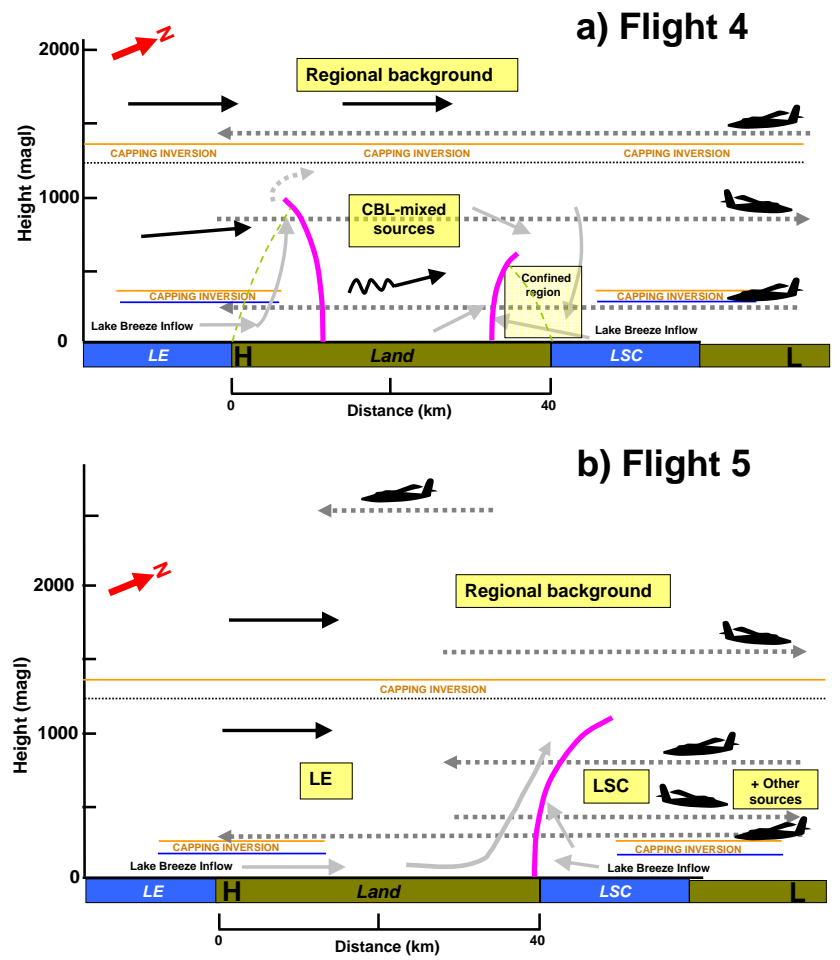

Fig. 10. Conceptual models of the flow in the vicinity of a lake-breeze circulation for (a) Flight 4 and (b) Flight 5 based on the interpretation of aircraft, model and trajectory data. Black straight arrows=synoptic flow, black, squiggly arrow $=$ convective boundary layer motion, dashed, dark grey horizontal arrows = flight path/direction, dashed, solid grey arrows=lake-breeze motion, light grey arrow $=$ slower flow due to effects from LE return flow, $\mathrm{H}=$ Harrow, $\mathrm{L}=$ Lambton.

The air parcel then drops close to the surface in the downdraft behind the LSC front and moves onshore in the LSC lake breeze in a helical pattern. Helical trajectories in lakebreeze circulations have been previously reported (Lyons and Olsson, 1973; Lyons and Cole, 1976; Lyons et al., 1995). Although not a common pathway, the trajectory shows that air in the CBL at 12:00 LT is connected to the air mass behind the LSC front via a helical circulation that completes a circuit in $4 \pm 1 \mathrm{~h}$.

\subsection{Conceptual models of the lake-breeze circulations}

Conceptual models of the flow in the vicinity of the lakebreeze circulations on 25 June for Flights 4 and 5 are proposed in Fig. 10. The models are based on an integration of the aircraft, model and trajectory data previously discussed. The aircraft flight path is illustrated as grey dashed arrows showing the altitude and direction of flight; the black arrows indicate the large scale movement and the grey arrows show the lake-breeze motions. In Fig. 10a (Flight 4), the CBL containing a mix of emissions from various sources across LE 
and Detroit/Windsor is bounded by the LE and LSC lakebreeze fronts over land. The black, squiggly arrow in the CBL depicts the observed convection motion. Regional air containing $\mathrm{SO}_{2}$ and $\mathrm{SO}_{4}^{2-}$ from source areas southwest of $\mathrm{LE}$ are transported into the region with the LE lake-breeze front acting as a boundary between LE and CBL air. The CBL contains air composed of a mix of pollutants from the Detroit/Windsor urban area, as well as sources at the west end of LE. The aircraft data clearly shows upward vertical motion at the LE front where air is advected and transported northward in the synoptic flow. The dashed grey arrow (Fig. 10a) represents the region of reduced wind speeds associated with effects from the LE return flow as previously discussed. Model simulations indicate transport of pollutants from the CBL and Detroit/Windsor area to over LSC that are, at least partially, caught in a downdraft over the south end of LSC. A downdraft was observed in the aircraft data behind the LSC lake-breeze front and both observations and model data show that pollutants were advected at low altitudes ( $<$ $300 \mathrm{~m}$ a.g.l.) in the LSC inflow toward the south shore of LSC. Model simulations show that pollutants are lofted upwards at the LSC front and returned back over LSC, along the LSC convergence zone toward Detroit/Windsor. The trajectory in Fig. 9 indicates that some of the CBL air can be entrained into the LSC lake-breeze system through a helical circulation pattern. In Fig. 10b (Flight 5), much of the heterogeneity observed during Flight 4 has disappeared and the region is more homogeneous in pollutant concentrations with the exception of high mixing ratios north of LSC. The available observations and model results indicate that pollutants in the CBL in Flight 4 were continually lofted at the LE and LSC fronts while the two fronts gradually merged together by Flight 5 , and either caught in the LSC lake-breeze circulation or transported northward in the synoptic flow and brought downward through convective mixing north of the lake.

Figure 11 shows some of the main features of the Flight 4 lake-breeze circulations in perspective view: the surface position of the lake-breeze fronts are shown as magenta lines, and the circulation flows are shown as arrows coloured according to altitude. Note that in order to demonstrate the lake-breeze flows, the vertical dimension of the arrows, relative to the horizontal dimension, has been greatly exaggerated - in reality, these circulations occur within a very shallow vertical layer of the troposphere. Synoptic flow is from the southwest and below $800 \mathrm{~m}$ a.g.l., the lake-breeze circulation creates two regions of uplift at the LE and LSC lakebreeze fronts. There is a subsidence (downdraft) region over the southern and eastern end of LSC with onshore flow associated with the LSC lake-breeze front at $<300 \mathrm{~m}$ a.g.l. Forward trajectories suggest a helical recirculation moving west along the LSC front (not illustrated). By Flight 5, the LE and LSC fronts have merged together.

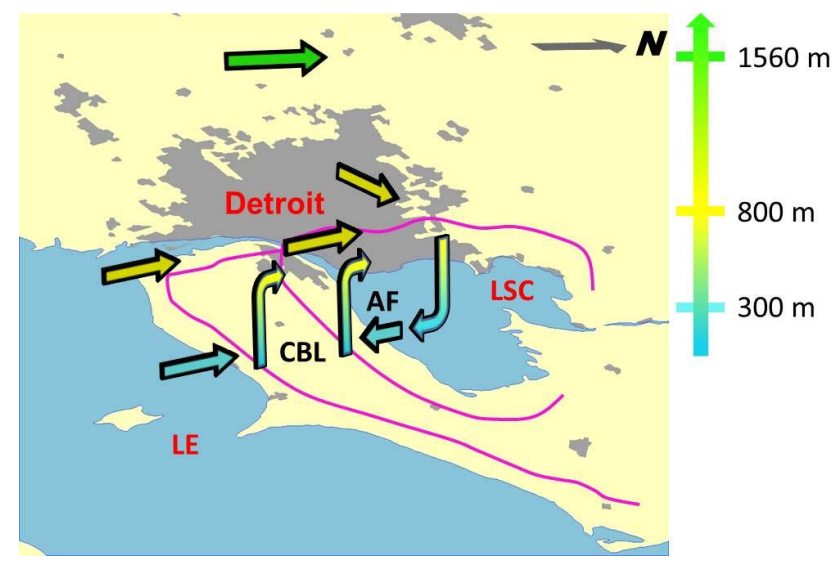

Fig. 11. Flight 4 perspective view. Surface position of lake-breeze fronts shown as magenta lines and the lake-breeze motions shown as arrows coloured according to altitude.

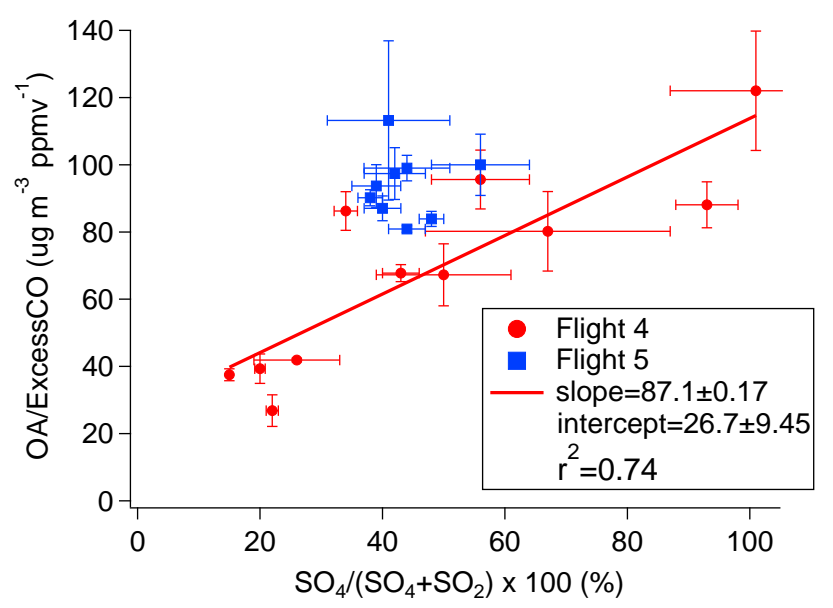

Fig. 12. Correlation of $\mathrm{OA} / \Delta \mathrm{CO}$ with $\mathrm{SO}_{4}^{2-} /\left(\mathrm{SO}_{2}+\mathrm{SO}_{4}^{2-}\right) \times 100$ across all air mass types for Flight 4 and 5 . Linear regression line fitted to Flight 4 data. The error bars are the standard deviations for each point.

\subsection{Impacts of the lake breezes on air mass processing}

Increases in the $\mathrm{OA} / \Delta \mathrm{CO}$ ratio are considered to be indicative of photochemical processes forming secondary organic aerosol (SOA) (DeCarlo et al., 2008, 2010; Kleinman et al., 2008), and thus can be used as a proxy for SOA formation. Similarly, changes in the ratio $\mathrm{SO}_{4}^{2-} /\left(\mathrm{SO}_{2}+\mathrm{SO}_{4}^{2-}\right)$ indicate different degrees of $\mathrm{SO}_{2}$ oxidation in the atmosphere (Hennigan et al., 2006; Quinn et al., 2005). Assuming no depositional losses, the dominant process affecting the ratios are those contributing to the chemical evolution of the aerosol. Figure 12 shows the relationship between $\mathrm{OA} / \Delta \mathrm{CO}$ and $\mathrm{SO}_{4}^{2-} /\left(\mathrm{SO}_{2}+\mathrm{SO}_{4}^{2-}\right)$. Each point represents an average of an air mass type which are defined below. OA is ratioed to $\Delta \mathrm{CO}$ to account for mixing and dilution; $\triangle \mathrm{CO}$ is determined as $\left(\mathrm{CO}-\mathrm{CO}_{\text {background }}\right)$, where $\mathrm{CO}_{\text {background }}$ for each flight 
was taken from an average of $\mathrm{CO}$ above the boundary layer and/or during periods where the aircraft was minimally influenced from anthropogenic emissions. Both $\mathrm{OA}$ and $\mathrm{SO}_{4}^{2-}$ are secondary aerosols resulting from concurrent chemical processing in an air parcel, and as such they are expected to be related in air masses on regional scales (i.e., at locations at least a certain distance downwind $(\sim>100 \mathrm{~km})$ of the main locations of their precursor emissions). However, the relative magnitudes of $\mathrm{OA}$ and $\mathrm{SO}_{4}^{2-}$ formation depend on the mixture and concentrations of $\mathrm{SO}_{2}$ and precursor hydrocarbons. Figure 12 shows that the relationship between $\mathrm{OA} / \Delta \mathrm{CO}$ and $\mathrm{SO}_{4}^{2-} /\left(\mathrm{SO}_{2}+\mathrm{SO}_{4}^{2-}\right) \times 100$ for Flight 5 is confined to a narrow range of OA production $\left(\sim 2.25 \mu \mathrm{g} \mathrm{m}^{-3} \mathrm{ppmv}^{-1} \%^{-1}\right)$, whereas in Flight 4, a linear relationship is observed with a range of $\mathrm{OA}$ production (relative to $\mathrm{SO}_{4}^{2-}$ production) extending from $1.2-1.75 \mu \mathrm{g} \mathrm{m}^{-3} \mathrm{ppmv}^{-1} \%^{-1}$. The relationship between $\mathrm{OA} / \Delta \mathrm{CO}$ and $\mathrm{SO}_{4}^{2-} /\left(\mathrm{SO}_{2}+\mathrm{SO}_{4}^{2-}\right)$ in Flight 4 provides a relatively convenient gauge of how much and how fast $\mathrm{OA}$ is formed since $\mathrm{SO}_{2}$ conversion in clear air is a better understood process and can be obtained through modelling. The rate of $\mathrm{SO}_{2}$ conversion in clear air has been reported at 1-3\% $\mathrm{h}^{-1}$ (Newman et al., 1981; Davis et al., 1979; Luria and Sievering, 1991) and can be further derived from the model. The modelled $\mathrm{SO}_{4}^{2-}$ production rate at 12:00 LT for $285 \mathrm{~m}$ a.g.l. for the study domain is shown in Fig. 13 and indicates that the regional background $\mathrm{SO}_{4}^{2-}$ production rate (non-plume influenced and non-lake-breeze influenced) is about $1-2 \% \mathrm{~h}^{-1}$, though much higher $\left(>20 \% \mathrm{~h}^{-1}\right)$ closer to sources and in high concentration plumes. The $\mathrm{OA}$ formation rate for regional background air is determined by multiplying the slope in Fig. 12 (Flight 4, $m=87.1 \mu \mathrm{g} \mathrm{m}^{-3} \mathrm{ppmv}^{-1} \%^{-1}$ ) by the regional background $\mathrm{SO}_{4}^{2-}$ formation rates taken from Fig. $13\left(1-2 \% \mathrm{~h}^{-1}\right)$. Thus, the regional background OA formation rate is $0.87-1.7 \mu \mathrm{g} \mathrm{m}^{-3} \mathrm{ppmv}^{-1} \mathrm{~h}^{-1}$. The regional background formation rates of $\mathrm{OA}$ and $\mathrm{SO}_{4}^{2-}$ are used as reference points in the following analysis for determining if the production rates could be enhanced in the lake-breeze recirculation.

Following on the analysis of air mass boundaries and movement in response to the lake breezes (summarized in Fig. 10), time slices of aircraft data were selected that represent different air mass "types" (shown as shaded boxes in Figs. 3 and 4). The selection of air mass types is as follows: RegB represents regional air along flight tracks above the boundary layer; LE represents air originating over LE and characterized by low pollutant concentrations with the exception of $\mathrm{SO}_{2}$ and $\mathrm{SO}_{4}^{2-}$ from power plants across LE; $\mathrm{CBL}$ is a section of the boundary layer closest to the LSC lake-breeze front and most influenced by lake-breeze circulations; $\mathrm{AF}$ represents air in the downdraft region of the LSC lake-breeze front; and LSC is air least affected by recent land-based emissions and lake-breeze circulations. Changes in the chemical characteristics of $\mathrm{OA}$ and $\mathrm{SO}_{4}^{2-}$ in these air masses are expected to reflect the influence of the lake-breeze circulations.

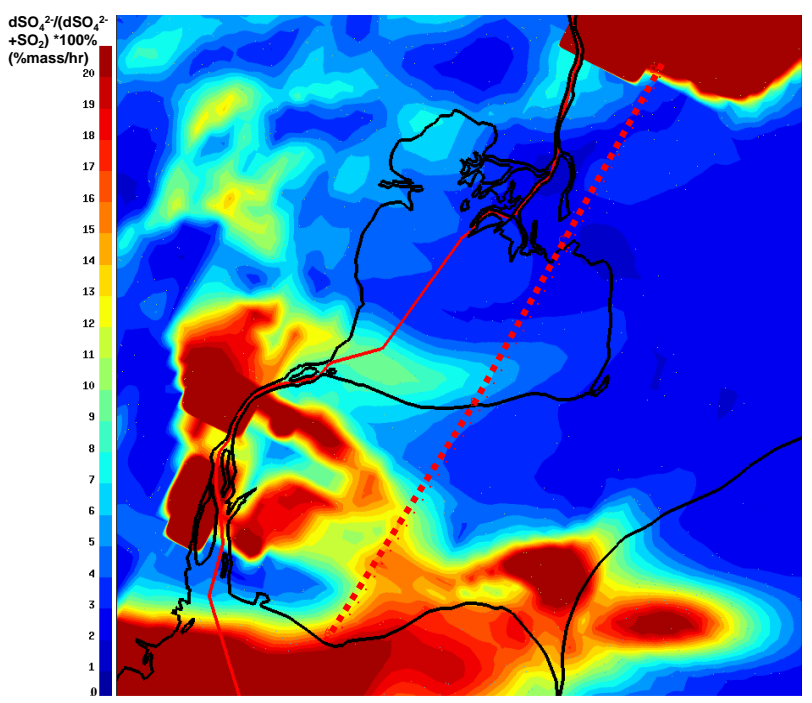

Fig. 13. Model-predicted $\mathrm{SO}_{4}^{2-}$ production rate in $\% \mathrm{~h}^{-1}$ at 12:00 LT for the study domain at $285 \mathrm{~m}$ a.g.l. Dashed red line is the aircraft transect.
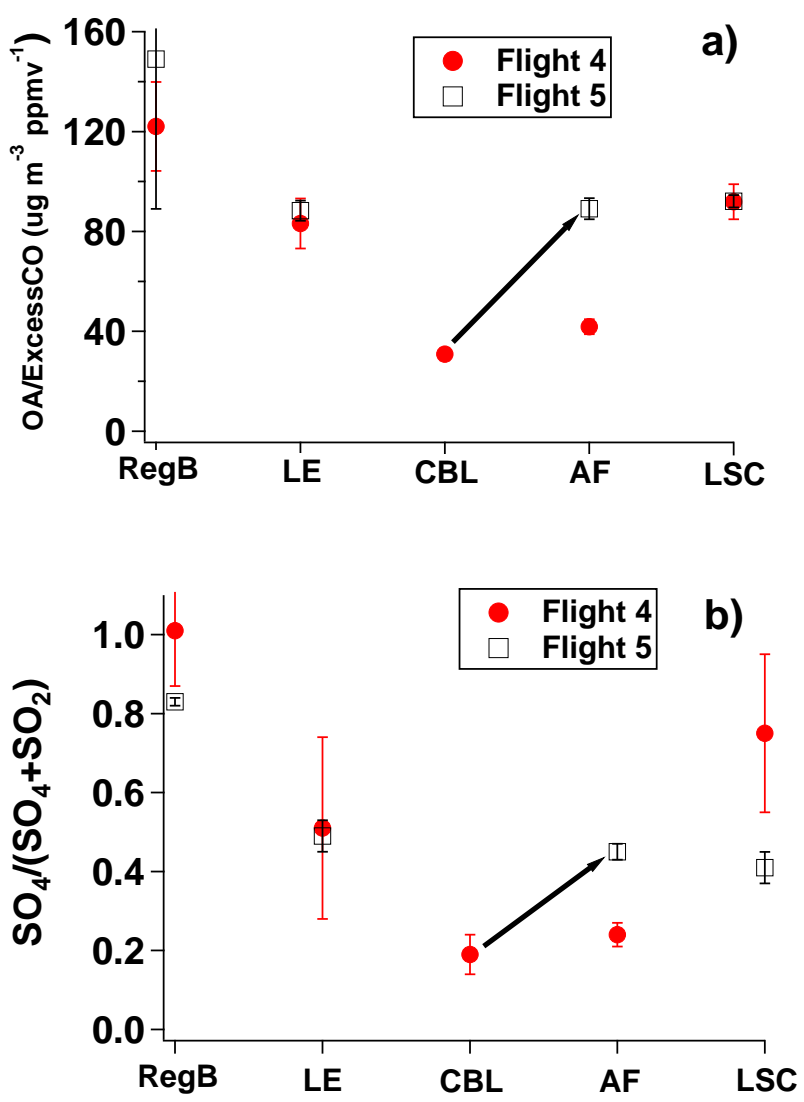

Fig. 14. (a) $\mathrm{OA} / \Delta \mathrm{CO}$ and (b) $\mathrm{SO}_{4}^{2-} /\left(\mathrm{SO}_{2}+\mathrm{SO}_{4}^{2-}\right)$ as a function of air mass type. 
In Fig. 14, the average and standard deviation of the $\mathrm{OA} / \Delta \mathrm{CO}$ and $\mathrm{SO}_{4}^{2-} /\left(\mathrm{SO}_{2}+\mathrm{SO}_{4}^{2-}\right)$ ratios are shown for each air mass type. The $\mathrm{OA} / \Delta \mathrm{CO}$ ratios in Flight 4 span a larger range of values, $91.1 \mu \mathrm{g} \mathrm{m}^{-3} \mathrm{ppmv}^{-1}$, compared to Flight 5 $\left(60.7 \mu \mathrm{g} \mathrm{m}^{-3} \mathrm{ppmv}^{-1}\right)$. Similarly, the $\mathrm{SO}_{4}^{2-} /\left(\mathrm{SO}_{2}+\mathrm{SO}_{4}^{2-}\right)$ ratio is more variable in Flight 4 compared to Flight 5. In addition, the OA/ $\triangle \mathrm{CO}$ ratio shows a general increase from Flight 4 to Flight 5 . These ratios highlight the spatial heterogeneity in the earlier flight, largely induced by the separation of air mass types due to the lake-breeze boundaries, and the subsequent transition to a comparatively homogeneous air mass during the later afternoon flight. The highest $\mathrm{OA} / \Delta \mathrm{CO}$ ratios are in RegB for both Flight 4 and Flight 5, suggesting similarities in the chemical composition of regional background air arriving in the study region throughout the day. In Flight 4 (Fig. 14a), the aircraft measurements in the CBL reflect a mixture of pollutant sources from Detroit/Windsor and from the west end of LE, and as such the low $\mathrm{OA} / \Delta \mathrm{CO}$ value, $30.9 \pm 2.5 \mu \mathrm{g} \mathrm{m}^{-3} \mathrm{ppmv}^{-1}$ indicates limited photochemical processing. This is consistent with reported values for unprocessed urban air. DeCarlo et al. (2008) note that the lowest ratio for relatively "fresh" urban air over Mexico City and surrounding region was $\sim 35 \mu \mathrm{g} \mathrm{sm}^{-3} \mathrm{ppm}^{-1}$. For similarly fresh urban air, Kleinman et al. (2007b) showed a ratio of $\sim 18 \mu \mathrm{g} \mathrm{m}^{-3} \mathrm{ppmv}^{-1}$. Figure $14 \mathrm{~b}$ shows $\mathrm{SO}_{4}^{2-} /\left(\mathrm{SO}_{2}+\mathrm{SO}_{4}^{2-}\right)$ ratios in the CBL that are consistent with an air mass that has undergone limited processing of $\mathrm{SO}_{2}$. Compared to the $\mathrm{CBL}$, the ratios over the lakes (LE and LSC) in Flight 4 reflect air masses that have been further processed.

In Flight 4, as most of these air masses are largely "unconnected" due to the lake-breeze induced boundaries, the variability in the extent of processing is not surprising. However, based on the interpretation of the LSC recirculation inferred from Flight 4 and 5 observations and modelling results, air masses in the CBL appear to be connected to that behind the LSC lake-breeze front (AF). Particles in the CBL are hypothesized to move aloft over the LSC front towards the north into the zone labelled as AF and then to descend and be recirculated through the onshore flow. The forward trajectory analyses (Fig. 9) suggests that the recirculation time is $4 \pm 1 \mathrm{~h}$. Thus, the CBL in Flight 4 and the AF in Flight 5 can be compared to determine if the lake-breeze recirculation results in changes in particle mass locally.

In Fig. 14a (Flight 4), the $\mathrm{OA} / \Delta \mathrm{CO}$ ratio in the $\mathrm{AF}$ air mass (behind the LSC lake-breeze front) $\left(89.1 \pm 4.2 \mu \mathrm{g} \mathrm{m}^{-3} \mathrm{ppmv}^{-1}\right)$ is higher compared to the $\mathrm{CBL}$ by $58.2 \mu \mathrm{g} \mathrm{m}^{-3} \mathrm{ppmv}^{-1}$. If the complete recirculation time is $3.0 \mathrm{~h}$, the rate of increase in the $\mathrm{OA} / \Delta \mathrm{CO}$ ratio is $19.4 \mu \mathrm{g} \mathrm{m}^{-3} \mathrm{ppmv}^{-1} \mathrm{~h}^{-1}$, but if the recirculation time is closer to $5.0 \mathrm{~h}$, the increase corresponds to $11.6 \mu \mathrm{g} \mathrm{m}^{-3} \mathrm{ppmv}^{-1} \mathrm{~h}^{-1}$. Thus, the OA formation rate (relative to excess $\mathrm{CO}$ ) determined in the lake-breeze recirculation, 11.6-19.4 $\mu \mathrm{g} \mathrm{m}^{-3} \mathrm{ppmv}^{-1} \mathrm{~h}^{-1}$, shows a significant enhancement over the regional background formation values inferred above $\left(0.87-1.7 \mu \mathrm{g} \mathrm{m}^{-3} \mathrm{ppmv}^{-1} \mathrm{~h}^{-1}\right)$. From Fig. $14 \mathrm{~b}$, the $\mathrm{SO}_{2}$ conversion rate can be similarly estimated. The average $\mathrm{SO}_{4}^{2-} /\left(\mathrm{SO}_{2}+\mathrm{SO}_{4}^{2-}\right)$ ratio in the $\mathrm{AF}$ air mass of $0.45 \pm 0.03$ and in the CBL of $0.19 \pm 0.03$ results in an estimated $\mathrm{SO}_{2}$ conversion rate to range between $5.0 \% \mathrm{~h}^{-1}$ (5h recirculation) and $8.8 \% \mathrm{~h}^{-1}(3 \mathrm{~h}$ recirculation). This suggests an enhancement over the non-plume influenced regional background formation rate $\left(1-2 \% \mathrm{~h}^{-1}\right)$ as predicted by the model. Enhancements in $\mathrm{SO}_{4}^{2-}$ and $\mathrm{OA}$ formation rates, relative to regional background formation rates, implies that lake-breeze circulations are an important dynamic in the formation of $\mathrm{SO}_{4}^{2-}$ and $\mathrm{SOA}$.

One possible explanation for such enhancements is through cloud processing. The presence of clouds can significantly increase the rate of $\mathrm{SO}_{2}$ oxidation (Luria and Sievering, 1991; Leaitch, 1996; Joos and Baltensperger, 1991) and SOA formation (Lim et al., 2005; Yu et al., 2005; Blando and Turpin, 2000;). An analysis of the cloud situation on 25 June indicates that at 11:00 LT there were no clouds present and then an hour later, $\sim 12: 00$ LT there was enhanced cloud growth at the LE and LSC fronts, and shallow cumulus cloud in the CBL. This was the time when the data in the CBL (Flight 4) were taken. Thus, clouds started to form just prior to when the measurements were made so it is likely that only limited cloud processing had taken place at this time. Between 13:00-14:00 LT, there was continued cloud growth at the LE and LSC fronts and significant enhanced cloud growth as the LE and LSC fronts merged. By 15:00 LT, there were no clouds and at $\sim 17: 00$ LT the Flight 5 measurements were made. Given the forward trajectory shows that the air in the CBL, at least partially, would have made it to behind the LSC front in about $4 \pm 1 \mathrm{~h}$, the Flight $5 \mathrm{AF}$ data would reflect more cloud processing time through clouds in the CBL, as well as processing through cloud at the LSC front. Therefore, it is possible that cloud processing contributed to the enhancements in $\mathrm{SO}_{4}^{2-}$ and $\mathrm{OA}$ formation rates.

A second explanation is that the effective confinement of pollutants behind the LSC front may have prevented the dilution of pollutants from further mixing and led to elevated oxidant and precursor concentrations, and therefore enhanced oxidation of primary pollutants including $\mathrm{SO}_{2}$ and organics. Both processes may be at work in the study region. Regardless of the processes, the lake-breeze front apparently led to locally enhanced $\mathrm{SO}_{2}$ (and probably organic aerosol precursors) and increased production of $\mathrm{SO}_{4}^{2-}$ and SOA.

\section{Conclusions}

High time-resolved aircraft data, concurrent surface measurements and meteorological and air quality model simulations were explored in a highly integrated manner to diagnose the processes influencing aerosol chemistry for a polluted BAQS-Met case associated with a well-developed 
lake-breeze circulation. This was based upon two aircraft flights (Flights 4 and 5 on 25 June 2007) in southwestern Ontario where horizontal transects across the entire lake-breeze circulation at multiple altitudes were performed. Air mass boundaries due to lake-breeze fronts were identified in the aircraft meteorological (dewpoint temperature and vertical gust velocity) and chemical data, which were consistent with the frontal locations determined from surface observations and satellite and radar images (Sills et al., 2011). The meteorological model was also found to simulate the conditions during the first flight reasonably well.

Cross-sectional plots created from the aircraft horizontal transects indicated that in the early afternoon flight (Flight 4), elevated mixing ratios of $\mathrm{CO}$ and $\mathrm{SO}_{2}$ were well-mixed vertically within a CBL and bounded by the LE and LSC fronts. Back trajectories indicated that the origin of these pollutants was from the west end of LE and the Detroit/Windsor area. Elevated pollutant concentrations were also observed aloft on the lake side of the LSC front and also closer to the surface, which was assumed to be due to subsiding air or downdrafts both observed and modelled. This area of high concentration did not extend far away from the front, thus indicating that the circulation pattern tended to confine pollutants in the lake-modified air relatively close to the front. By the late afternoon (Flight 5), the region was largely enveloped in lake air and pollutants observed in Flight 4 were displaced by the merging LE and LSC fronts. The available observations and model results indicate that pollutants in the CBL in Flight 4 were continually lofted at the LE and LSC fronts while the two fronts gradually merged together by Flight 5 , and either caught in the LSC lake-breeze circulation and confined by the LSC onshore flow along the south shore of LSC, or transported northward in the synoptic flow and brought downward through convective mixing north of the lake. Forward trajectories suggest that air parcels caught in the LSC recirculation travelled a helical trajectory along the LSC front toward Detroit/Windsor with a complete recirculation time of $4 \pm 1 \mathrm{~h}$.

This detailed, integrated approach led to the development of conceptual models that summarizes the complex 3-D circulation patterns and its interaction with the synoptic flow. An attempt was then made at determining local $\mathrm{SO}_{4}^{2-}$ and OA production rates in the LSC lake-breeze circulation. Using the relationship between $\mathrm{OA} / \triangle \mathrm{CO}$ and $\mathrm{SO}_{4}^{2-} /\left(\mathrm{SO}_{2}+\mathrm{SO}_{4}^{2-}\right)$ (Fig. 12) as a gauge of how much OA is formed and a background formation rate for $\mathrm{SO}_{4}^{2-}$ ranging between $1-2 \% \mathrm{~h}^{-1}$ taken from the model, the regional background formation rate for OA was calculated to be $0.87-$ $1.7 \mu \mathrm{g} \mathrm{m}^{-3} \mathrm{ppmv}^{-1} \mathrm{~h}^{-1}$. Based on the interpretation of the LSC lake-breeze circulation, air masses in the CBL (Flight 4) and behind the LSC front (AF, Flight 5) (Figs. 10, 11) were compared to determine formation rates of $\mathrm{OA}$ and $\mathrm{SO}_{4}^{2-}$. The maximum and minimum values (5.0 and $3.0 \mathrm{~h}$, respectively) of the best estimates for recirculation time (or processing time) provide upper and lower bounds on the formation rates.
The OA formation rate (relative to excess $\mathrm{CO}$ in ppmv), determined in the lake-breeze recirculation was found to be 11.6-19.4 $\mu^{-3} \mathrm{~m}^{-3} \mathrm{ppmv}^{-1} \mathrm{~h}^{-1}$ which shows an enhancement over the regional background formation values inferred above $\left(0.87-1.7 \mu \mathrm{g} \mathrm{m}^{-3} \mathrm{ppmv}^{-1} \mathrm{~h}^{-1}\right)$. The $\mathrm{SO}_{4}^{2-}$ formation rate is estimated to range between $5.0-8.8 \% \mathrm{~h}^{-1}$, also enhanced over the regional background formation rate. The enhanced formation rates relative to regional background rates implies that lake-breeze circulations are an important dynamic in the local, near-source formation of $\mathrm{SO}_{4}^{2-}$ and SOA. The presence of cumulus clouds associated with the lakebreeze fronts suggests that these enhancements could be due to cloud processes. Additionally, the effective confinement of pollutants along the LSC south shore may have limited pollutant dilution thereby leading to elevated oxidant concentrations, and enhanced oxidation of primary pollutants including $\mathrm{SO}_{2}$ and organics. Continued research is required to better understand the physical mechanisms and chemical processes within lake-breeze circulations, specifically related to the formation of PM, and the relative importance of PM components.

Acknowledgements. The authors wish to thank Walter Strapp and Steve Bacic for their contributions during the aircraft field program, as well as Geoff Stupple, Ilan Levy, and Julie Narayan for their significant efforts in processing data and producing plots. We also wish to acknowledge the contribution of the pilots, technical crew and scientists at the National Research Council of Canada. R. McLaren acknowledges funding from NSERC and the Ontario Ministry of the Environment.

Edited by: J. Abbatt

\section{References}

Allan, J. D., Jimenez, J. L., Coe, H., Bower, K. N., Williams, P. I., and Worsnop, D. R.: Quantitative sampling using an Aerodyne aerosol mass spectrometer. Part 1: techniques of data interpretation and error analysis, J. Geophys. Res. Atmos, 108, 4090, doi:10.1029/2002JD002358, 2003.

Allan, J. D., Bower, K. N., Coe, H., Boudries, H., Jayne, J. T., Canagaratna, M. R., Millet, D. B., Goldstein, A. H., Quinn, P. K., Weber, R. J., and Worsnop, D. R.: Submicron aerosol composition at Trinidad Head, CA during ITCT 2K2, its relationship with gas phase volatile organic carbon and assessment of instrument performance, J. Geophys. Res. Atmos., 109, D23S24, doi:10.1029/2003JD004208, 2004.

Bahreini, R., Dunlea, E. J., Matthew, B. M., Simons, C., Docherty, K. S., DeCarlo, P. F., Jimenez, J. L., Brock, C. A., and Middlebrook, A. M.: Design and operation of a pressure-controlled inlet for airborne sampling with an aerodynamic aerosol lens, Aerosol Sci. Technol., 42, 465-471, doi:10.1080/02786820802178514, 2008.

Biggs, W. G. and Graves, M. E.: A lake breeze index, J. Appl. Meteorol., 1, 474-480, 1962. 
Blando, J. D. and Turpin, B. J.: Secondary organic aerosol formation in cloud and fog droplets: a literature evaluation of plausibility, Atmos. Environ., 24, 1623-1632, 2000.

Bouchlaghem, K., Nsom, B., and Lattrache, N.: Air quality variation under sea breeze conditions in Tunisian coasts, European Journal of Scientific Research, 23, 518-527, 2008.

CEP: Carolina Environmental Program, Sparse Matrix Operator Kernel Emission (SMOKE) modelling system, University of North Carolina, Carolina Environmental Programs, Chapel Hill, NC, available at: http://www.smoke-model.org/index.cfm, 2003.

Chan, T. W., Brook, J. R., Smallwood, G. J., and Lu, G.: Timeresolved measurements of black carbon light absorption enhancement in urban and near-urban locations of Southern Ontario, Canada, Atmos. Chem. Phys. Discuss., 10, 19939-19980, doi:10.5194/acpd-10-19939-2010, 2010.

Cheng, W.-L.: Ozone distribution in coastal central Taiwan under sea-breeze conditions, Atmos. Environ., 36, 3445-3459, 2002.

Cho, S., Makar, P. A., Lee, W. S., Herage, T., Liggio, J., Li, S. M., Wiens, B., and Graham, L.: Evaluation of a unified regional air quality modeling system (AURAMS) using PrAIRie2005 field study data: The effects of emissions data accuracy on particle sulphate predictions, Atmos. Environ., 43, 1864-1877, 2009.

Côté, J., Gravel, S., Méthot, A., Patoine, A., Roch, M., and Staniforth, A.: The operational CMC-MRB Global Environmental Multiscale (GEM) model. Part 1: Design considerations and formulation, Mon. Weather Rev. , 126, 1373-1395, 1998.

D'Amours, R. and Pagé, P.: Atmospheric transport models for environmental emergencies, available at: http://collaboration.cmc.ec.gc.ca/cmc/cmoi/product_guide/ docs/lib/model-eco_urgences_e.pdf, 2001.

Davis, D. D., Heaps, W., Philen, W., and Mcgee, T.: Boundary layer measurements of the $\mathrm{OH}$ radical in the vicinity of an isolated power plant plume: $\mathrm{SO}_{2}$ and $\mathrm{NO}_{2}$ chemical conversion times, Atmos. Environ., 13, 1197-12031, 1979.

DeCarlo, P. F., Kimmel, J. R., Trimborn, A., Northway, M. J., Jayne, J. T., Aiken, A. C., Gonin, M., Fuhrer, K., Horvath, T., Docherty, K., Worsnop, D. R., and Jimenez, J. L.: Fielddeployable, high-resolution, time-of-flight aerosol mass spectrometer, Anal. Chem., 78, 8281-8289, 2006.

DeCarlo, P. F., Dunlea, E. J., Kimmel, J. R., Aiken, A. C., Sueper, D., Crounse, J., Wennberg, P. O., Emmons, L., Shinozuka, Y., Clarke, A., Zhou, J., Tomlinson, J., Collins, D. R., Knapp, D., Weinheimer, A. J., Montzka, D. D., Campos, T., and Jimenez, J. L.: Fast airborne aerosol size and chemistry measurements above Mexico City and Central Mexico during the MILAGRO campaign, Atmos. Chem. Phys., 8, 4027-4048, doi:10.5194/acp8-4027-2008, 2008.

DeCarlo, P. F., Ulbrich, I. M., Crounse, J., de Foy, B., Dunlea, E. J., Aiken, A. C., Knapp, D., Weinheimer, A. J., Campos, T., Wennberg, P. O., and Jimenez, J. L.: Investigation of the sources and processing of organic aerosol over the Central Mexican Plateau from aircraft measurements during MILAGRO, Atmos. Chem. Phys., 10, 5257-5280, doi:10.5194/acp-10-52572010, 2010.

Drewnick, F., Schwab, J. J., Jayne, J. T., Canagaratna, M., Worsnop, D. R., and Demerjian, K. L.: Measurement of ambient aerosol composition during the PMTACS-NY 2001 using an aerosol mass spectrometer. Part I: Mass concentrations, Aerosol Sci. Tech., 38, 92-103, 2004.
Dunlea, E. J., DeCarlo, P. F., Aiken, A. C., Kimmel, J. R., Peltier, R. E., Weber, R. J., Tomlinson, J., Collins, D. R., Shinozuka, Y., McNaughton, C. S., Howell, S. G., Clarke, A. D., Emmons, L. K., Apel, E. C., Pfister, G. G., van Donkelaar, A., Martin, R. V., Millet, D. B., Heald, C. L., and Jimenez, J. L.: Evolution of Asian aerosols during transpacific transport in INTEX-B, Atmos. Chem. Phys., 9, 7257-7287, doi:10.5194/acp-9-7257-2009, 2009.

Garratt, J. R.: The internal boundary layer - a review, Bound.-Lay. Meteorol., 50, 171-203, 1990.

Gong, W., Dastoor, A. P., Bouchet, V. S., Gong, S., Makar, P. A., Moran, M. D., Pabla, B., M'enard, S., Crevier, L.-P., Cousineau, S., and Venkatesh, S.:, Cloud processing of gases and aerosols in a regional air quality model (AURAMS), Atmos. Res., 82, 248275, 2006.

Hastie, D. R., Narayan, J., Schiller, C., Niki, H., Shepson, P. B., Sills, D. M. L., Taylor, P. A., Moroz, Wm. J., Drummond, J. W., Reid, N., Taylor, R., Roussel, P. B., and Melo, O. T.: Observational evidence for the impact of the lake breeze circulation on ozone concentrations in Southern Ontario, Atmos. Environ., 33, 323-335, 1999.

Hayden, K. L., Macdonald, A. M., Gong, W., Toom-Sauntry, D., Anlauf, K. G., Leithead, A., Li, S.-M., Leaitch, W. R., and Noone, K.: Cloud processing of nitrate, J. Geophys. Res., 113, D18201, doi:10.1029/2007JD009732, 2008.

Hennigan, C. J., Sandholm, S., Saewung, K., Stickel, R. E., Huey, L. G., and Weber, R. J.: Influence of Ohio River valley emissions on fine particle sulfate measured from aircraft over large regions of the eastern United States and Canada during INTEX-NA, J. Geophys. Res., 111, D24S04, doi:10.1029/2006JD007282, 2006.

Houyoux, M. R., Vukovich, J. M., Coats Jr., C. J., and Wheeler, N. J. M.: Emission inventory development and processing for the Seasonal Model for Regional Air Quality (SMRAQ) project, J. Geophys. Res., 105, 9079-9090, 2000.

Huffman, J. A., Jayne, J. T., Drewnick, F., Aiken, A. C., Onasch, T., Worsnop, D. R. and Jimenez, J. L.: Design, Modeling, Optimization, and Experimental Tests of a Particle Beam Width Probe for the Aerodyne Aerosol Mass Spectrometer, Aerosol Sci. Tech., 39, 1143-1163, 2005, doi:10.1080/02786820500423782, 2005.

Jayne, J. T., Leard, D. C., Zhang, X., Davidovits, P., Smith, K. A., Kolb, C. E., and Worsnop, D. R.: Development of an Aerosol Mass Spectrometer for size and composition of submicron particles, Aerosol Sci. Tech., 33, 49-70, 2000.

Jimenez, J. L., Jayne, J. T., Shi, Q., Kolb, C. E., Worsnop, D. R., Yourshaw, I., Seinfeld, J. H., Flagan, R. C., Zhang, X., Smith, K. A., Morris, J., and Davidovits, P.: Ambient aerosol sampling with an aerosol mass spectrometer, J. Geophys. Res. Atmos, 108, 8425, doi:10.1029/2001JD001213, 2003.

Joos, F. and Baltensperger, V.: A field study on chemistry, S(IV) oxidation rates and vertical transport during fog conditions, Atmos. Environ., 25A, 217-230, 1991.

Kitada, T. and Kitagawa, E.: Numerical analysis of the role of sea breeze fronts on air quality in coastal and inland polluted areas, Atmos. Environ., 24A, 1545-1559, 1990.

Kleinman, L. I., Daum, P. H., Lee, Y. N., Senum, G. I., Springston, S. R., Wang, J., Berkowitz, C., Hubbe, J., Zaveri, R. A., Brechtel, F. J., Jayne, J. T., Onasch, R. B., and Worsnop, D. R.: Aircraft observations of aerosol composition and ageing in New England and Mid-Atlantic States during the summer 2002 New Eng- 
land Air Quality Study field campaign, J. Geophys. Res., 112, D09310, doi:10.1029/2006JD007786, 2007.

Kleinman, L. I., Springston, S. R., Daum, P. H., Lee, Y.-N., Nunnermacker, L. J., Senum, G. I., Wang, J., Weinstein-Lloyd, J., Alexander, M. L., Hubbe, J., Ortega, J., Canagaratna, M. R., and Jayne, J.: The time evolution of aerosol composition over the Mexico City plateau, Atmos. Chem. Phys., 8, 1559-1575, doi:10.5194/acp-8-1559-2008, 2008.

Leaitch, W. R.: Observations pertaining to the effect of chemical transformation in cloud on the anthropogenic aerosol size distribution, Aerosol Sci. Tech., 25, 157-173, 1996.

Lim, H.-J., Carlton, A. G., and Turpin, B. J.: Isoprene forms secondary organic aerosol through cloud processing: model simulations, Environ. Sci. Technol., 39, 4441-4446, 2005.

Lin, C.-H., Wu, Y.-L., and Lai, C.-H.: Ozone reservoir layers in a coastal environment - a case study in southern Taiwan, Atmos. Chem. Phys., 10, 4439-4452, doi:10.5194/acp-10-4439-2010, 2010.

Liu, P. S. K., Leaitch, W. R., Strapp, J. W., and Wasey, M. A.: Response of particle measuring systems airborne ASASP and PCASP to $\mathrm{NaCl}$ and latex particles, Aerosol Sci. Tech., 16, 8395, 1992.

Liu, P. S. K., Deng, R., Smith, K. A., Williams, L. R., Jayne, J. T., Canagaratna, M. R., Moore, K., Onasch, T. B., Worsnop, D. R. and Deshler, T.: Transmission Efficiency of an Aerodynamic Focusing Lens System: Comparison of Model Calculations and Laboratory Measurements for the Aerodyne Aerosol Mass Spectrometer, Aerosol Sci. Tech., 41, 721-733, doi:10.1080/02786820701422278, 2007.

Lu, R. and Turco, R. P.: Air pollutant transport in a coastal environment, Part I: two-dimensional simulations of sea breeze and mountain effects, J. Atmos. Sci., 51, 2285-2308, 1994.

Luria, M. and Sievering, H.: Heterogeneous and homogeneous oxidation of $\mathrm{SO}_{2}$ in the remote marine atmosphere, Atmos. Environ., 25, 1489-1496, 1991.

Lyons, W. A.: The climatology and prediction of the Chicago lake breeze, J. Appl. Meteorol., 11, 1259-1270, 1972.

Lyons, W. A. and Cole, H. S.: Photochemical oxidant transport: mesoscale lake breeze and synoptic-scale aspects, J. Appl. Meteorol., 733-743, 1976.

Lyons, W. A. and Olsson, L. E.: Detailed micrometeorological studies of air pollution dispersion in the Chicago lake breeze, Mon. Weather Rev., 101, 387-403, 1973.

Lyons, W. A. and Pease S. R.: Detection of particulate air pollution plumes from major point sources using ERTS-1 imagery, Bull. Amer. Meteor. Soc., 54, 1163-1170, 1973.

Lyons, W. A., Pielke, R. A., Tremback, C. J., Walko, R. L., Moon, D. A., and Keen, C. S.: Modeling impacts of mesoscale vertical motions upon coastal zone air pollution dispersion, Atmos. Environ., 29, 283-301, 1995.

Makar, P. A., Moran, M. D., Zheng, Q., Cousineau, S., Sassi, M., Duhamel, A., Besner, M., Davignon, D., Crevier, L.-P., and Bouchet, V. S.: Modelling the impacts of ammonia emissions reductions on North American air quality, Atmos. Chem. Phys., 9, 7183-7212, doi:10.5194/acp-9-7183-2009, 2009.

Makar, P. A., Zhang, J., Gong, W., Stroud, C., Sills, D., Hayden, K. L., Brook, J., Levy, I., Mihele, C., Moran, M. D., Tarasick, D. W., He, H., and Plummer, D.: Mass tracking for chemical analysis: the causes of ozone formation in southern Ontario dur- ing BAQS-Met 2007, Atmos. Chem. Phys., 10, 11151-11173, doi:10.5194/acp-10-11151-2010, 2010.

Matthew, B. M., Middlebrook, A. M. and Onasch, R. B.: Collection Efficiencies in an Aerodyne Aerosol Mass Spectrometer as a Function of Particle Phase for Laboratory Generated Aerosols. Aerosol Sci. Tech., 42, 884-898, doi:10.1080/02786820802356797, 2008.

McElroy, M. B. and Smith, T. B.: Vertical pollutant distributions and boundary layer structure observed by airborne lidar near the complex California coastline, Atmos. Environ., 20, 1555-1566, 1986.

McKendry, I. G., Steyn, D. G., Lundgren, J., Hoff, R. M., Strapp, W., Anlauf, K., Froude, F., Martin, J. B., Banta, R. M., and Olivier, L. D.: Elevated ozone layers and vertical down-mixing over the Lower Fraser Valley, BC, Atmos. Environ., 14, 21352146, 1997.

National Research Council of Canada: Twin Otter Operations in Southern Ontario in Support of Project BAQSMeT - Border Air Quality Study, Meteorological - 2007, Report, 1, EDTR-FT-285, Srinivasan, R. and Bastian M., March 2008.

Newman, L.: Atmospheric oxidation of sulphur dioxide: a review as viewed from power plant and smelter plume studies, Atmos. Environ., 15, 2231-2239, 1981.

OME: Border Air Quality Study-An ambient air quality overview for southwestern Ontario (Summer 2007), Air Monitoring and Reporting Section, Environmental Monitoring and Reporting Branch, Ontario Ministry of the Environment, 2008.

Quinn, P. K., Bates, T. S., Baynard, T., Clarke, A. D., Onasch, T. B., Wang, W., Rood, M. J., Andrews, E., Allan, J., Carrico, C. M., Coffman, D., and Worsnop, D.: Impact of particulate organic matter on the relative humidity dependence of light scattering: a simplified parameterization, Geophys. Res. Lett., 32, L22809, doi:10.1029/2005GL024322, 2005.

Quinn, P. K., Bates, T. S., Coffman, D., Onasch, T. B., Worsnop, D., Baynard, T., de Gouw, J. A., Goldan, P. D., Kuster, W. C., Williams, E., Roberts, J. M., Lerner, B., Stohl, A., Pettersson, A., and Lovejoy, E. R.: Impacts of Sources and Aging on Submicrometer Aerosol Properties in the Marine Boundary Layer Across the Gulf of Maine, J. Geophys. Res., 111, D23S36, doi:10.1029/2006JD007582, 2006.

Reid, N. W., Niki, H., Hastie, D. R., Shepson, P. B., Roussel, P., Melo, O. T., Mackay, G., Drummond, J., Schiff, H. I., Poissant, L., and Moroz, W.: The southern Ontario oxidant study (SONTOS): Overview and case studies for 1992, Atmos. Environ., 30, 2125-2132, 1996.

Salcedo, D., Onasch, T. B., Canagaratna, M. R., Dzepina, K., Huffman, J. A., Jayne, J. T., Worsnop, D. R., Kolb, C. E., Weimer, S., Drewnick, F., Allan, J. D., Delia, A. E., and Jimenez, J. L.: Technical Note: Use of a beam width probe in an Aerosol Mass Spectrometer to monitor particle collection efficiency in the field, Atmos. Chem. Phys., 7, 549-556, doi:10.5194/acp-7-549-2007, 2007.

Sills, D. M. L.: Lake and land breezes in southwestern Ontario: observations, analyses and numerical modelling, $\mathrm{PhD}$ dissertation, CRESS, York University, 338 pp., 1998.

Sills, D. M. L., Brook, J. R., Levy, I., Makar, P. A., Zhang, J., and Taylor, P. A.: Lake breezes in the southern Great Lakes region and their influence during BAQS-Met 2007, Atmos. Chem. Phys., 11, 7955-7973, doi:10.5194/acp-11-7955-2011, 2011. 
Simpson, J. E.: Sea breeze and local wind, Cambridge University Press, Cambridge, UK, 234 pp., 1994.

Slowik, J. G., Brook, J., Chang, R. Y.-W, Evans, G. J., Hayden, K., Cheong, C.-H., Li, S.-M., Liggio, J., Liu, P. S. K., McGuire, M., Mihele, C., Sjostedt, S., Vlasenko, S., and Abbatt, J. P. D.: Photochemical processing of organic aerosol at nearby continental sites: contrast between urban plumes and regional aerosol, Atmos. Chem. Phys. 2991-3006, doi:10.5194/acp-11-2991-2011, 2011. 2010.
Snyder, B. J. and Strawbridge, K. B.: Meteorological analysis of the Pacific 2001 air quality field study, Atmos. Environ., 38, 57335743, 2004.

Yu, J. Z., Huang, X.-F., Xu, J., and Hu, M.: When aerosol sulphate goes up, so does oxalate: implication for the formation mechanisms of oxalate, Environ. Sci. Technol., 39, 128-133, 2005.

Zhang, Q., Alfarra, M. R., Worsnop, D. R., Allan, J. D., Coe, H., Canagaratna, M. R., and Jimenez, J. L.: Deconvolution and quantification of hydrocarbon-like and oxygenated organic aerosols based on aerosol mass spectrometry, Environ., Sci. Technol., 39, 4938-4952, doi:10.1021/es0485681, 2005. 